\title{
ARTICLES
}

\section{OBJEGTIVITY IN CONSTITUTIONAL LAW}

\author{
ROBERT W. BENNETT $\dagger$
}

\section{INTRODUCTION}

\section{A. Objectivity and Authoritativeness}

Concern that there be "objective" bases for judicial decisions has long been prominent in American jurisprudence. This concern has played an important part in discussions of judge-made common law and of the judicial role in statutory interpretation. But concern with judicial objectivity has been particularly persistent in debates about constitutional interpretation, where the formal checks on judicial decisionmaking are much weaker than they are for common law and statutory decisions.

The concern with judicial objectivity is evident in the current debate about the nature and legitimacy of constitutional review. This debate has focused on particularly broad constitutional language, like that of the fourteenth amendment, where the text itself provides little constraint on judicial action. ${ }^{1}$ On one side of the debate are constitutional

† Professor of Law, Northwestern University. B.A. 1962, LL.B. 1965, Harvard University. Much of the work on this Article was done during a year as Visiting Professor at the University of Southern California Law Center, where Dean Bice and the splendid USC faculty provided a congenial and stimulating environment. This Article profited from faculty workshops devoted to it at USC and Northwestern and at the University of San Diego School of Law. Outside of those contexts, helpful comments were provided on earlier drafts by many people, but I know they will understand if I reserve mention here for my appreciation to Nat Nathanson. Nat died on November 8 , 1983. In discussing this paper, as on so many occasions in the past, Nat offered wise and generous counsel. More important, in the years I knew him, Nat Nathanson set scholarly and personal standards that kept me striving and that I hope always will.

1 This is not to say that the language of the fourteenth amendment provides no constraint at all on what can be done in its name. It is hard to see, for instance, how the equal protection clause could be understood as an explanation of the structure of the atom; or even-getting closer to home-how it could be interpreted to forbid the transfer of land from the federal Department of the Interior to the Department of Agriculture, without a showing of the effects of the transfer. On the constraining effect of constitutional language, see Schauer, An Essay on Constitutional Language, 29 UCLA L. REv. 797, 809-12, 824-31 (1982). See generally Moore, The Semantics of Judging, 54 S. CAL. L. REv. 151 (1981).

I will touch on the constraining influence of relatively specific constitutional language below, see infra text accompanying notes $35-38$, but there is no dispute that the 
"interpretivists"2 or "originalists,"3 who argue that constitutional language, understood in light of the substantive intentions or values ${ }^{4}$ behind its enactment, is the sole proper source for constitutional interpretation. For originalists, obedience to original intent imposes essential constraint on judicial choice that constitutional language alone does not provide. On the other side of the debate are "noninterpretivists" or "nonoriginalists" who believe it is legitimate for judges to look beyond text and original intention in interpreting constitutional language. These nonoriginalists, however, are divided on what particular sources should replace or supplement originalist sources and on how to justify their use.

Despite their differences, both originalists and nonoriginalists in-

language of the fourteenth amendment is relatively unconstraining. My principal concern here is with constraining influences apart from enacted language, and the fourteenth amendment provides a relatively pure context in which to examine those influences. For this reason, in the text I will generally ignore any constraining influence of the language of the fourteenth amendment.

2 Use of this term is usually traced to Grey, Do We Have An Unwritten Constitution?, 27 STAN. L. REv. 703 (1975). John Ely popularized the term first in law review articles, see, e.g., Ely, Constitutional Interpretivism: Its Allure and Impossibility, 53 IND. L. J. 399 (1978), and then in J. ElY, DemocraCY AND Distrust (1980) [hereinafter cited as J. ELY, DisTrust].

3 I will generally employ Professor Brest's term, "originalism," for this approach to constitutional decisionmaking. See Brest, The Misconceived Quest for the Original Understanding, 60 B.U.L. REv. 204 (1980). I avoid the less accurate "literalism" I once used to describe essentially the same approach, see Bennett, "Mere" Rationality In Constitutional Law: Judicial Review and Democratic Theory, 67 CALIF. L. REv. 1049,1089 (1979), as well as the more common "interpretivism," because "originalism" better captures the static pretense of the approach that seems to me to be its principal flaw. See infra text accompanying notes 65-76.

"Originalists often use the notions of "intentions" and "values" without careful attention to their relationship. Both can be very slippery terms. Ronald Dworkin, for instance, points out that intentions in the use of governing language that others are to interpret might represent either hopes or expectations. Dworkin, The Forum of Principle, 56 N.Y.U. L. REv. 469, 483-85 (1981). By "intentions" originalists generally mean a desire that something be accomplished or not accomplished through constitutional language. "Values" are assumed to be considerations that mattered to the framers of the language in a way that shaped their intentions. Because I will be concerned with originalist claims for intentions or values, I will not attempt any more refined definitions and will often use the words interchangeably in the text.

Originalists also tend to ignore those aspects of the constitutional framers' states of mind that had to do with the way the language they were enacting would be interpreted-what is sometimes called the framers' "interpretive intent." See Brest, supra note 3 , at 215. Originalists are not drawn, for instance, to the suggestion sometimes made in the name of the original fourteenth amendment intent that the judiciary has been delegated the power of continuing refinement and redefinition of constitutionally fundamental values. Compare Bickel, The Original Understanding and the Segregation Decision, 68 HaRv. L. REv. 1, 63-64 (1955) with Monaghan, Our Perfect Constitution, 56 N.Y.U. L. REv. 353, 361-62 (1981). I mean to exclude such aspects of original intention by limiting what originalists embrace to "substantive" intentions or values. 
sist upon external constraints on judicial choice, and both often express their insistence as a concern that judges be objective. The notion of judicial objectivity, however, is ambiguous in a way that the participants on both sides of the debate fail to appreciate. "Objective" is often used to mean contextually correct or authoritatively established, as when a multiple choice examination is described as an "objective" test because each question has only one "correct" answer. In this strong sense, objective sources for decisions would be ones that some authoritative standard identifies as yielding contextually correct decisions. I will refer to judicial objectivity in this sense as judicial reliance on authoritative sources for decision. A second and weaker sense of "objective" refers to the use of sources for decision external to the decider's own (or "subjective") standards or values, without necessarily insisting that those external sources be authoritative. It is in this sense that I will use the term "objective."

These two senses of objectivity are conflated in the writing of both originalists and nonoriginalists. After showing this conflation, I will explore preliminarily in this Introduction the relationship between authoritativeness and objectivity and then turn in the body of the Article to the extent to which they can be said to characterize the enterprise of constitutional interpretation.

\section{Originalists' Conflation of Objectivity and Authoritativeness}

A mingling of the notions of objectivity in the sense of acceptance of authoritative direction and objectivity in the sense of reliance on sources of values external to those of the deciding judge comes through in what the self-styled originalist Joseph Grano says about the appeal of originalism as an objective basis for judicial decisions:

When a judge engages in interpretivist constitutional review, objective sources of judgment exist. Often ... "the most important datum bearing on what was intended is the constitutional language itself." In addition historical events, legislative history, and the structure of the Constitution help inform the judge's interpretational task ....

... The sincere interpretivist judge ... must infer meaning from provisions in the written document while [the sincere noninterpretivist judge] can pursue extra-constitutional sources of judgment, such as the writings of moral philosophers.

Were the issue over legitimacy otherwise close, 
noninterpretivism should nonetheless be rejected, because objective criteria to select these extra-constitutional sources of judgment do not exist. . . . [A]ll such extra-constitutional sources ... inevitably reduce to the judge's personal preferences.

It is not at all clear in this passage in which of the two ways distinguished above Grano is using the notion of objectivity. He denies that "the writings of moral philosophers" can be "objective sources of judgment," and his reference to the "judge's personal preferences" suggests that he means objectivity in the sense of reliance on external sources of values. ${ }^{6}$ In that sense, however, the writings of moral philosophers would seem to qualify as objective sources. More likely, for Grano "objectivity" is linked with the constitutional authoritativeness that he believes only originalism can provide. ${ }^{7}$ It is only in this sense that the writings of moral philosophers are not "objective."

The same sort of conceptual mingling is present when the originalist Robert Bork writes:

the Court's power is legitimate only if it has, and can demonstrate in reasoned opinions that it has, a valid theory, derived from the Constitution, of the respective spheres of majority and minority freedom. If it does not have such a theory but merely imposes its own value choices, or worse if it pretends to have a theory but actually follows its own predilections, the Court violates the postulates of the Madisonian model that alone justifies its power. ${ }^{8}$

Bork does not use the term "objective" at all in this passage, ${ }^{\circ}$ but he unites the concerns about objectivity and authoritativeness when he

- Grano, Judicial Review and a Written Constitution in a Democratic Society, 28 WAYNe L. REv. 1, 18-19 (1981) (footnotes omitted). See also R. Berger, GoverNMENT BY JUDICIARY 284-85 (1977).

- Grano elsewhere refers to noninterpretivism as "a hopelessly subjective methodology." Grano, supra note 5, at 20; see also id. at 29.

7 Grano does seem to separate the concerns when he acknowledges that reliance on a Gallup poll "might [be] an objective source of judgment" but would be "theoretically indefensible." Id. at 37-38. More commonly, he associates objectivity with correctness or indisputableness. See, e.g., id. at 20, 23-24. 3 (1971).

Bork, Neutral Principles and Some First Amendment Problems, 47 IND. L.J. 1,

In another portion of the article from which the passage comes, Bork writes disparagingly of constitutional decisions based on "some system of moral or ethical values that has no objective or intrinsic validity of its own and about which men can and do differ." Id. at 10. The suggestion here is that objectivity is possible only when dispute is not, and that in turn tends to conflate the notions of objectivity and authoritativeness. 
contrasts "a valid theory, derived from the Constitution" with a court's improvisation of "its own value choices" or following "its own predilections" (even when that takes the form of "pretend[ing] to have a theory"), as if these possibilities occupied the field. ${ }^{10}$ For Bork, originalism supplies a legitimating vision of constitutional authoritativeness; by reference to originalism, and originalism alone, Bork's ideal arbiter can identify correct and incorrect constitutional decisions. ${ }^{11}$ Bork implies that either a decision is obedient to such constitutional authority and hence "valid," or it is "subjective," a matter of purely personal preference. No room is left for mere judicial objectivity.

It is understandable that the concerns about authoritativeness and objectivity are merged in the writing of originalists. Originalists' strongest argument in the current debate is their appeal to the "authoritative" status of the Constitution, but this appeal camouflages the distinction between the constitutional language and the intentions with which it was promulgated. The status of the text as authority is relatively unproblematic, while that of intentions, as we shall see, is not. The appeal of judicial objectivity, on the other hand, is almost universal. Our conception of law and the duty owed to it does not envision judges in constitutional cases simply substituting their personal value judgments for the legislative value judgments. ${ }^{12}$ To the extent that originalists can associate uncontroversial objectivity with the more problematic authoritativeness of originalist sources, the appeal of their doctrine is enhanced.

\section{Nonoriginalists' Conflation of Objectivity and Authoritativeness}

The inclination to merge objectivity and authoritativeness is not

10 Other expressions Bork uses to capture offensive bases for decision are "the mere will of the Justices," id. at 3, "unguided discretion of judges," $i d$. at 4, a judge's "imposition of his own will," $i d$., and "the Justices' personal beliefs about what interests or gratifications ought to be protected," $i d$. at 12 . At one point he contrasts such bases for decision with a regime in which there is "guidance" for judges, id. at 18, and at another with decisions we can know "are correct," $i d$. at 5 . Bork also laments judicial action "without adequate guidance from constitutional materials." Id. at 17.

11 Those with a vision of constitutional authoritativeness do not usually view that vision as inconsistent with reserving a place for judicial "discretion" in decisions. In that sense there need not be only one authoritatively "right answer." I shall return to the tension this produces, but in any case, constitutional authoritativeness, in its originalist and in other versions, is most decidedly used as a basis for labeling some decisions authoritatively "wrong."

12 For expressions of this view by persons holding very different views on constitutional interpretation, see R. DWORKIN, TAKING RIGHTS SERIOUSLY 126 (1977); L. LUSKY, BY WHAT RIGHT? (1975); Bork, supra note 8, at 6; Michelman, Welfare Rights in a Constitutional Democracy, 1979 WASH. U.L.Q. 659, 665. 
limited to originalists. Arrayed against originalism in the contemporary debate is a variety of commentators sharply divided on what to put in its stead. This group, like the originalists, wants to describe, explain, and justify a set of constraints on judicial choice; also like the originalists, in doing so, they often merge notions of authoritativeness and objectivity. Ronald Dworkin, for instance, calls for "a fusion of constitutional law and moral theory"13 as an antidote to judicial discretion. He repeatedly suggests that the fusion will allow moral and political philosophy to lead a sufficiently diligent and talented judge to right answers to questions of constitutional law. ${ }^{14}$ In that way, a philosophically inspired theory provides not only an objective source for judicial values but the authoritative source as well. ${ }^{15}$

Other nonoriginalists are skeptical that moral and political philosophy can show the way to constitutional authoritativeness. Even for them, however, the appeal of providing an authoritative source for answering questions of constitutional law is great. Notable in succumbing to that appeal is John Hart Ely, who presents an aphilosophical basis for authoritative constraint on judicial choice with his representation reinforcement theory of judicial review. ${ }^{\mathbf{1 6}}$

Ely initially seems concerned with judicial objectivity in the weaker sense of relying on values external to the judge's individual values. He argues that the sources usually suggested for identifying constitutionally "fundamental" values-natural law, reason, consensus, moral philosophy-are all so indeterminate or manipulable in the hands of judges that they leave room for any conclusion a judge decides to reach on other grounds. ${ }^{17}$ Ely finds such susceptibility to manipulation intolerable. Like the originalists, and like Dworkin, Ely shuns judicial "subjectivity," but finds his own vision of constitutional authoritativeness to be the only alternative.

To provide a substitute for these manipulable sources of values, Ely argues that representativeness in the political process is the overarching constitutional value that must guide constitutional decisions. According to Ely, the appropriate function of the Court in implementing the fourteenth amendment is to assure representativeness directly

13 R. Dworkin, supra note 12 , at 149.

14 See id. at 279-90; Dworkin, No Right Answer?, 53 N.Y.U. L. REv. 1 (1978).

16 Michael Perry's recent book attempts to justify "noninterpretive" judicial review on matters of personal liberty because of "the possibility that there may indeed be right answers-discoverable right answers-to fundamental political-moral problems." M. Perry, The Constitution, the Courts, and Human Rights 102 (1982) (emphasis in original).

16 The theory is elaborated most fully in J. ELY, Distrusr, supra note 2.

12 See id. at 43-72. 
when that is possible, and beyond that, to overturn political decisions that can confidently be identified as infirm in their representative credentials. ${ }^{18}$ This theory, like Dworkin's, purports to yield right or authoritative answers based on values that are not "subjective."

\section{B. The Tension Between Objectivity and Authoritativeness}

To avoid a possible misunderstanding at the outset, in sorting out

18 The criticism of Ely's theory has been devastating, generally proceeding along two lines. First, representativeness is not an uncontroversial choice as the overarching constitutional value. See, e.g., Tushnet, Darkness on the Edge of Town: The Contributions of John Hart Ely to Constitutional Theory, 89 YALE L.J. 1037, 1045-48 (1980); Lynch, Book Review, 80 ColuM. L. REv. 857, 859-64 (1980). To accept the premise of Ely's theory is thus to resolve the very sort of debatable question Ely faults other theories for having to confront. This first criticism is in effect aimed at Ely's claim for the authoritativeness of a representation reinforcement theory of judicial review.

The second criticism is aimed at the theory's pretense of objectivity. Critics point out that representativeness alone provides no basis for deciding constitutional questions; courts cannot identify a failure of representativeness without reference to views about the ends of government or society. See, e.g., Brest, The Substance of Process, 42 OHIO ST. L.J. 131 (1981); Tribe, The Puzzling Persistence of Process-Based Constitutional Theories, 89 YALE L.J.'1063 (1980). (Each of these articles contains elements of the first criticism as well.) See also Dworkin, supra note 4, at 500-16. Reliance on such a theory is again the sort of pitfall Ely claims his theory can avoid.

This second criticism would not be justified if representativeness could be identified with the formal right to participate in the decisionmaking process. Thus, if exclusion from the franchise were the necessary and sufficient condition for a failure of representativeness, then that failure could presumably be identified without recourse to any theory about the ends of government or society. Neither Ely nor our constitutional law, however, has been satisfied with any such simple basis for constitutional guidance.

The problem is well illustrated by a comparison between the approaches taken under the fourteenth amendment to the interests of children, on the one hand, and to those of aliens on the other. Neither group has the franchise, the formal device for assuring the "representativeness" of political outcomes. For children this has not seemed particularly troublesome, since their interests are often thought to be represented by adults with the franchise. For aliens, however, both Ely, see J. Ely, DisTRUST, supra note 2, at 151,161-62, and the developed body of constitutional law are less confident that their interests will be adequately represented. Aliens are thus often treated, appropriately in Ely's view, as a "discrete and insular minority" whose interests deserve special judicial solicitude. See, e.g., Graham v. Richardson, 403 U.S. 365 (1971). (The phrase "discrete and insular minority" comes, of course, from Justice Stone's seminal Carolene Products footnote. United States v. Carolene Prods. Co., 304 U.S. 144, 152 n.4 (1938).) The most plausible explanation for the distinction between aliens and children, however, lies in the substance of the treatment of the two by the political processes. By and large, we assume that children are treated fairly but aliens often are not. The example of children shows that the substance of political decisions can be evidence that sufficient weight has been given to the interests of some excluded from representative processes. To reach this conclusion, however, we must employ some scheme of values, however well- or ill-formed, of how fairness is to be judged in our society-in this case, fairness to children and to aliens. Whatever informs those judgments of fairness will be effectively indistinguishable in susceptibility to manipulation from those bases Ely rejects as too manipulable. Ely's theory can thus lay no more claim to objectivity (or at least none of a qualitatively different sort) than those it seeks to replace. 
issues of objectivity and authoritativeness, we should distinguish sources of values from a mechanism of review by which their use is tested. In the contemporary United States, constitutional decisions of the Supreme Court are accepted as final. ${ }^{19}$ This finality makes those decisions authoritative, but it does not necessarily make the sources on which those decisions are based authoritative, or even objective. The finality of Supreme Court decisions may reinforce concern about judicial objectivity, for we are helpless in the face of arbitrariness by the body with the final say. Concern about judicial objectivity that can only be provided by a reviewing authority, however, is unresolvable. If our search were for a reviewing authority, we would only be faced with the question of what constrains that reviewing authority and so on to infinite regress. Our inquiry is into the determinants of judicial decisionmaking-constraint by decisional sources and not by some reviewing agency. In that sense, judicial objectivity or obedience to constitutional authoritativeness must be something that judges have the power to choose or to refuse to choose.

If we confine our attention to the nature and sources of constitutional values, it is apparent that use of an authoritative source would produce objective constraint on judicial choice (unless judges themselves were authoritatively given the power of "personal" choice). Initially it might seem that the converse is also true. If the range of "objective" sources from which a court could choose is unlimited and there are no rules or devices of preference among the available choices (or definition of the judicial role that directs the judge to some of those sources rather than others), then the distinction between the chooser's values and the values chosen collapses. Under these assumptions, objectivity without authoritativeness would be impossible.

A distinction between objective sources of values and an authoritative one emerges, however, if we question the assumptions. If judges feel themselves obliged to turn to some objective sources of values in preference to others, then the scope of their choice is constrained, but not necessarily through identification of an authoritative basis for decision. The puzzle of judicial objectivity is whether any such obligation can be identified and how its appeal might be distinguished from the obligation owed authority.

We can catch an initial glimpse of the distinction between objective and authoritative sources of values by considering the role of judicial

19 See Cooper v. Aaron, 358 U.S. 1, 18 (1958) (noting that Chief Justice Marshall in Marbury v. Madison, 5 U.S. (1 Cranch) 137, 177 (1803), "declared the basic principle that the federal judiciary is supreme in the exposition of the law of the Constitution"). 
precedent in the adjudicatory process. Precedent is often called "authority,"20 but, for reasons I will explore in some detail, ${ }^{21}$ the nature and extent of the fidelity payed to precedent is difficult to define or calibrate and is apparently much dependent upon context. We have neither a theory nor a practice of treating precedent as directing judges to invariably right decisions in constitutional law. Even when the question before the court cannot be distinguished from one previously disposed of, the precedent can be overruled. If precedent constrains judicial choice, it does so by supplying nonsubjective but also nonauthoritative sources for judicial decisions. Moreover, if precedent does constrain in this way, it can do so only in irreconcilable tension with the desire for constitutional authoritativeness.

Among the originalists, Henry Monaghan seems to deny the tension between constraint on judicial choice by precedent and constitutional authoritativeness. Monaghan has taken up the cause of stare decisis. He sees the opponents of originalism as wanting to employ constitutional law to cure society's imperfections. He accuses them of pursuing a "perfectionist culture" that links "political morality with the Constitution."22 Despite this accusation, Monaghan would not overturn decisions inspired by perfectionism and incorrect by originalist lights. He is almost as critical of judges who ignore precedent as he is of perfectionists. He sees disrespect for precedent as a pressing problem "strongly reinforced by the fundamental premises of perfectionist theory." 23

Monaghan's position on precedent is anomalous. ${ }^{24}$ Monaghan sees originalism as providing a reasonably determinate basis for distinguishing right decisions from wrong ones. Like any authoritative scheme, such a use of originalism could be reconciled with respect for precedent by a simple ipse dixit: the first time a problem comes up, the decisionmaker applies the authoritative scheme as best he can; thereafter he employs precedent even if that precedent appears upon reflection to have been wrong. Such an approach, however, is bound to be continually unsatisfying. For all the contemporary court need do is screw up its courage and decide now what it feels its predecessors should initially

${ }^{20}$ See, e.g., Friedman, Kagan, Cartwright \& Wheeler, State Supreme Courts: A Century of Style and Citation, 33 STAN. L. REv. 773, 792-94 (1981) [hereinafter cited as Style and Citation].

21 See infra notes 99-136 and accompanying text.

22 Monaghan, supra note 4, at 374.

${ }^{23}$ Id. at 390. See also Monaghan, Taking Supreme Court Opinions Seriously, 39 MD. L. REv. 1 (1979). (1982).

${ }^{24}$ See Easterbrook, Ways of Criticizing the Court, 95 HaRv. L. REv. 802, 811-31 
have decided. Once it has taken this step, its decision will become precedent and will stand supported both by the doctrine of stare decisis and by the additional fact that it is "right." For this reason, any theory of the substance of constitutional law that pretends to authoritativeness will readily overwhelm prior decisions it can brand as "wrong."

Thus, it is not surprising that most participants in the contemporary debate who rely on a vision of constitutional authoritativeness ignore the role of precedent. ${ }^{25} \mathrm{Ely}$, for instance, despite his abiding concern with constraining judges, apparently assigns no role to precedent. ${ }^{26}$ This leaves the impression that all decisions infirm in their representation reinforcement justification can and should be overruled.

Fleshing out an account of judicial objectivity, then, requires some definition of the judicial role that provides rules or devices of preference among objective sources without necessarily appealing to their authoritativeness. To identify such a judicial role is necessarily to assign the judiciary a task at once more subtle and more realistic than would champions of authoritativeness. Appeals to authoritativeness necessarily tend toward the mutual exclusivity of right and wrong decisions. They also direct one's attention to the substance of constitutional law and away from its processes. They tend toward substantive absolutes that initially entice but in the end become intellectual straightjackets that cannot hope to achieve the tasks assigned to them.

An emphasis on judicial objectivity can perhaps shake the judiciary loose from such sterile fetters by emphasizing the role of the adjudicatory process in producing the substance of constitutional law. The

${ }^{25}$ Dworkin does have an extensive discussion of the role of precedent. See $\mathrm{R}$. Dworkin, supra note 12, at 110-15. In addition, Frank Michelman, who has pursued the quest for constitutional authoritativeness, see, e.g., Michelman, The Supreme Court, 1968 Term-Foreword: On Protecting the Poor Through the Fourteenth Amendment, 83 Harv. L. Rev. 7 (1969) [hereinafter cited as Michelman, Protecting], discusses precedent very sensitively in Michelman, Constancy to an Ideal Object, 56 N.Y.U. L. REv. 406, 412-15 (1981) [hereinafter cited as Michelman, Constancy].

${ }^{28}$ Ely's Democracy and Distrust has no significant discussion of the role of precedent. It is its absence, rather than anything Ely explicitly says about precedent, that is so striking. One would have thought that questions about how precedent affects Ely's theory of judicial review are particularly important in light of his suggestions about the textual bases for the decisions he deems appropriate. Where a general review of the substance of political decisions is appropriate, Ely argues that it should proceed under the largely neglected ninth amendment and the privileges and immunities clause of the fourteenth amendment, rather than under the due process and equal protection clauses upon which the Supreme Court has leaned so heavily. J. ELY, DisTrust, supra note 2, at 11-41. If the Court were to agree with Ely and announce that conclusion, the status of many due process and equal protection decisions would inevitably be thrown into doubt. Constitutional law in the areas of the substance of those decisions would be deprived of a great deal of whatever stability it derives from the force of precedent. On the constraining role of precedent, see infra text accompanying notes 99-108. 
process of adjudication not only makes use of preexisting values in decisionmaking; it also inevitably reworks those values and shapes new ones for further use. If there can be objectivity without authoritativeness, then it may accommodate both constraint and change as part of a developmental process of law.

\section{Focus of the Critique}

I begin to work through the puzzle of judicial objectivity in the next part by taking seriously the originalist claim of authoritativeness for original substantive intentions. My focus will be on the problem of decision under the broad language of the fourteenth amendment. I will initially separate the authoritative status of constitutional language from that of original intention, but my principal concern is with authoritative and objective constraints apart from constitutional language. The fourteenth amendment context allows examination of those constraints in a relatively pure form.

I will not initially examine the claims that might be made by systems of moral philosophy to an authoritative status in constitutional law. ${ }^{27}$ If societal values some day coalesce around a set of moral principles sufficiently coherent to be called a "system," the claim of such a system to judicial obedience in constitutional cases might be compelling. For the present, however, it is clear that fundamental differences with far-reaching implications for constitutional questions continue to bedevil the efforts of moral and political philosophers. ${ }^{28}$ Unanswered questions raised about Ely's effort ${ }^{29}$ also suggest that no challenge to the appeal of originalism as authoritative is likely to come from the search for some unwritten transcendent "constitutional" value outside discourse on political morality (if there is such a thing). Thus, for the present, it seems to be originalism or nothing if we want a route to right answers, an authoritative basis for constitutional decisions. Part II of this Article is devoted to showing that, with that choice, we shall have to do with nothing, for no plausible version of originalism seems capable of providing authoritative answers to constitutional questions under the roomy language of the fourteenth amendment.

In part III, I will turn to the possibility of judicial objectivity without constitutional authoritativeness. My aim in part III is to de-

${ }^{27}$ I return later to the role of moral philosophy when I discuss Ronald Dworkin's theory. See infra text accompanying notes 147-64.

${ }_{28}$ See Alexander, Liberalism as Neutral Dialogue: Man and Manna in the Liberal State, 28 UCLA L. REv. 816, 819-26 (1981).

20 See supra note 18. 
scribe the judicial objectivity that exists and to suggest some reasons that it takes the form it does. My final concern in part III will be to make clear how my position differs from that of Ronald Dworkin in particular, who abjures originalism ${ }^{30}$ but reaches out for a constitutional authoritativeness that can accommodate a role for judicial precedent. That discussion will require attention to the thorny problem of consistency in constitutional decisionmaking. The journey through these issues of authoritativeness and objectivity will allow us to turn, in the conclusion, to the question whether in the final analysis it is useful to draw a distinction between the two.

\section{The Limit of Authoritativeness: The Failed PROMISE OF ORIGINALISM}

My discussion of originalism will not retrace the three most commonly discussed problems with the doctrine. These are the historiographical problem of determining intentions of people long ago, the conceptual difficulty of defining what in an individual's mental framework counts as a relevant part of intention, and the "summing" problem of developing a group intention for the complex activity of promulgating constitutional language that is carried on by many people in many different legislative bodies. These problems cast significant doubt on the claim of originalism to authoritativeness, but the literature on them is already rich and is growing. ${ }^{31}$ Instead, my focus will be on the decisional process of courts and in particular on the effect of the adjudicatory process on the values employed in decisions. The originalist claim for the authoritativeness of original intention depends in part upon an assumption of an ability to project that intention in a straight line over time, an assumption that ignores much about the reality of the

so Dworkin sometimes invokes the authority of original intention without accepting its constraints. See infra note 55 and accompanying text. Despite occasionally invoking original intention in support of his theory, for present purposes Dworkin is clearly not an originalist.

${ }^{31}$ On the summing problem, see Bennett, supra note 3, at 1071-73, 1090-92; Bice, Rationality Analysis in Constitutional Law, 65 MINN. L. REv. 1, 26-33 (1980); Brest, supra note 3, at 214-15; Dworkin, supra note 4, at 476-88; Monaghan, supra note 4 , at $375 \mathrm{n} .130$. Aspects of the conceptual difficulty are treated in Dworkin, supra note 4, at 483-97; Moore, supra note 1, at 246-70. For discussions of the historiographical problem, see Brest, supra note 3, at 211-23; Dworkin, supra note 4, at 47697; Monaghan, supra note 4, at 377; Munzer \& Nickel, Does the Constitution Mean What It Always Meant?, 77 Colum. L. Rev. 1029, 1030-33 (1977); Sandalow, Constitutional Interpretation, 79 MicH. L. REv. 1033 (1981); Tushnet, Following the Rules Laid Down: A Critique of Interpretivism and Neutral Principles, 96 HARv. L. Rev. $781,793-804$ (1983). As we shall see, the summing problem is bound up with the question of the authoritativeness of intention. See infra text accompanying notes 40-43. 
judicial task of adjudication.

My strategy in elaborating this difficulty is to take originalism seriously. I will show that a rigorous attempt to treat the framers' intentions as authoritative places far fewer constraints on judicial decisionmaking than originalists assume. If judges are to follow the framers' intentions, they must project those intentions over time. Any such projection will either make use of developing judicial experience, in which case it will not constrain judges as originalists think it will, or it will ignore considerations the framers would not have ignored had they been deciding, in which case it will lose its appeal as authoritative. I will demonstrate this central point through an example drawn from the law of contracts before applying it in the constitutional context.

Originalist writing emphasizes limiting the range of choices judges can appropriately make. If I am right, originalists' reliance on the authoritativeness of the framers' intentions to support their position is misplaced. Rather, it is a smokescreen for the value they place on judicial restraint, perhaps in turn fed by a political conservatism that some originalists sense will be served by tighter restraint. I do not denigrate the value placed on judicial restraint. My purpose, rather, is to disentangle that value from the originalist pretense (as well as the pretense of other authoritative schemes) so that the value placed on judicial restraint can be seen as what is really at stake.

\section{A. Language and Intention}

Henry Monaghan writes that:

The authoritative status of the written constitution is . . . an incontestable first principle for theorizing about American constitutional law. . . . For the purposes of legal reasoning, the binding quality of the constitutional text is itself incapable of and not in need of further demonstration. It is our master rule of recognition ....32

In the case of the fourteenth amendment, however, the text brings little constraint with it. Like other originalists, ${ }^{\text {ss }}$ Monaghan is very much concerned with constraint, which he attempts to achieve by clothing the motivating intention with the authoritativeness of the text. "[T]he text," Monaghan asserts, as if it goes without saying, "may be understood

32 Monaghan, supra note 4, at 383-84 (emphasis in original).

s3 See, e.g., R. BERGER, supra note 5, at 283-99; Bork, supra note 8, at 3-4. At times, Joseph Grano seems less concerned than other originalists with constraining judicial choice. See Grano, supra note 5, at 61-75. 
and usefully applied only if its purposes are understood."34 This leap from the authoritativeness of the constitutional language to that of the intentions or values of those who promulgated the language is an essential ingredient of the originalist dogma, but its justification is not at all clear.

Much use of language is characterized by vagueness, ambiguity, or both; ${ }^{35}$ and knowing the intention with which language was used can often be useful in clarifying vagueness or resolving ambiguity. Words themselves, however, do bring a degree of "objective" meaning with them-a meaning independent of the intentions of any author employing them. It is only through such objective meaning that language is useful as a vehicle for, among other things, expressing intentions. We can conclude that a thirty-year-old cannot meet the constitutional thirty-five year age requirement to be President ${ }^{36}$ without recourse to the intention with which the words were used. Similarly, while the sixth amendment right to a "public trial by an impartial jury"37 might be satisfied by a jury of six persons rather than the traditional twelve, ${ }^{\mathbf{3 8}}$ we do not have to consult the author's intentions to conclude that the guarantee would not be satisfied by having conviction or acquittal depend upon the defendant's ability to complete a crossword puzzle.

To say that language brings objective limits on the meaning that can be ascribed to it does not deny the pervasive presence of ambiguity, nor does it deny that the meaning of language can be manipulated through devices like legal fictions. Moreover, context has an important effect on meaning, and the meaning of language can and does change. To say that language imposes objective limits is only to assert that, in a particular context, language conveys and excludes a great deal of meaning without the interpreter's having to refer to the author's state of mind. If it did not, language would not occupy its preeminent place as a vehicle for human communication.

In addition, reference to intention cannot resolve ambiguity or clarify vagueness when the language was intentionally used with ambiguity or vagueness. Even if reference to intention might resolve a particular problem of interpretation, moreover, the intention of the user of

s4 Monaghan, supra note 4, at 375. By "its purposes" Monaghan clearly means the purposes of the people who enacted the provision. See id. at 375 n.130.

so For a discussion of the difference between the two and of other problems in the interpretation of governing language, see Moore, supra note 1, at 181-202.

se U.S. ConST. art. II, § 1, cl. 4.

s7 U.S. CoNST. amend. VI.

ss See Williams v. Florida, 399 U.S. 78 (1970) (upholding the constitutionality of a six-person jury in a criminal case). Monaghan seems to object to this decision on originalist grounds. Monaghan, supra note 4, at 375 n.132. 
the language need not be relevant, let alone determinative. In contract law, for instance, a reasonable interpretation placed on contractual language by the party to the contract who did not originate it is often preferred to an interpretation-even a reasonable one-of the party who did. ${ }^{39}$ The case for an "objective" meaning other than the author's might well be thought stronger in the context of constitutional or legislative interpretation where, unlike the case of the typical contract, the effect of the language on the author after passage is not systematically different in kind from its effect on other citizens.

Once text and intent are seen as separable, the former comfortably assumes authoritativeness in a way that the latter cannot. Only the text is adopted. 40 The problem of "summing" individual intentions to find the relevant one that vexes any search for original constitutional intent $^{41}$ does not exist for the text. We know exactly how to sum the votes necessary to promulgate constitutional language. In the amendment process, ${ }^{42}$ we also have a well-established, well-understood, and universally accepted mechanism for altering the constitutional text. There is nothing comparable for constitutional intention. ${ }^{43}$

Legal practice as well as theory exhibits a qualitative difference between the authority of text and of intention. There is substantial evidence of widespread failure by courts to accept original intention as authoritative, ${ }^{44}$ while no such body of evidence suggests that text can similarly be disdained. ${ }^{45}$ To the contrary, while the courts are equivocal

39 See Restatement (Second) of Contracts $§ 206$ (1981). Learned Hand said: "It makes not the least difference whether a promisor actually intends that meaning which the law will impose upon his words. The whole House of Bishops might satisfy us that he had intended something else, and it would make not a particle of difference in his obligation." Eustis Mining Co. v. Beer, Sondheimer \& Co., 239 F. 976, 984 (S.D.N.Y. 1917). Williston took the position "that a contract may be formed which is in accordance with the intention of neither party." S. WILLISTON, A TREATISE ON THE LAW OF CoNTRACTS $§ 95$ (3d ed. 1957).

10 See $1 \mathrm{~J}$. Story, Commentaries on the Constitution of the United States 389-90 (Boston 1833).

11 See supra note 31.

12 U.S. ConST. art. V.

43 For this reason, it is unfair to pass off noninterpretivists' reliance on the summing problem as a "debater's trick." Tushnet, supra note 31 , at 796 n.40.

"See Brest, supra note 3, at 224, 232-34.

45 Paul Brest suggests the contrary, but his examples are ones where the constitutional language is too open-ended to allow any easy conclusion of "derogation" from text. He says, for instance, that "even a generous reading of the fifth amendment" would not support the Court's incorporation of the restraints of equal protection into that amendment's due process clause. Id. at 233. It is not clear if the "reading" he has in mind relies on intention, but if it does not, the words of the fifth amendment's due process clause seem sufficiently vague to accommodate the Court's equal protection incorporation holdings. My disagreement with Brest on this point may be influenced by the latitude taken with the language of due process over the years, so that the vagueness 
in what they say about the authoritativeness of intent, ${ }^{46}$ they are much more respectful of what Chief Justice Marshall called "the authoritative language of the American people." gated language to command respect are undoubtedly diverse and perhaps mysterious to a degree. ${ }^{48}$ The subject of authoritativeness of constitutional language is beyond my present ambitions, but we can comfortably assume that the constitutional text is authoritative without concluding that the authoritativeness of original intent is necessarily implied. If original intent is to be authoritative, it must establish the claim on its own.

\section{B. The Authority of Intention}

\section{Potential Bases for the Authority of Intention}

Whatever claim to authoritativeness does attach to original intent would seem to depend on one or both of two assumptions. ${ }^{49}$ The first is a factual assumption that it was only through accident, inadvertence, or a desire to economize in the use of language that the intenders ${ }^{50}$ did not promulgate language that would more clearly have answered a question it was their "intention" to answer. If constitutional language is assumed to be authoritative, the intenders, as participants in the promulgation of the text, collectively had the authority (or have come to be seen to have had the authority) to bind constitutionally in any way they chose. If they failed to express their intentions only through accident or

of its "meaning" is in part a function of its use over time. But there is a plausible argument that the words of the due process clauses do not direct one to questions of process to the exclusion of substance. See Tribe, supra note 18, at 1066 n.9.

${ }^{46}$ See, e.g., Williams v. Florida, 399 U.S. 78, 122-29 (1970) (Harlan, J., concurring in result).

17 Cohens v. Virginia, 19 U.S. (6 Wheat.) 264, 381 (1821). Although the evidence is mixed, I think this fairly suggests the dominant attitude of the Supreme Court and of most commentators. See, e.g., Richardson v. Ramirez, 418 U.S. 24, $54-55$ (1974); United States v. Butler, 297 U.S. 1, $62-63$ (1936); Sturges v. Crowningshield, 17 U.S. (4 Wheat.) 122, 202-03 (1819); Gibbons, Keynote Address, 56 N.Y.U. L. REv. 260, 272 (1981); Michelman, Constancy, supra note 25, at 413, Munzer \& Nickel, supra 31 , at $1054-55$.

48 See Bennett, Abortion and Judicial Review: Of Burdens and Benefits, Hard Cases and Some Bad Law, 75 Nw. U.L. REv. 978, 981-82 (1981); Schauer, supra note 1 , at $809-11$.

${ }^{10}$ It is, of course, possible to assert as a first principle that original intent is authoritative without resort to substantiating reasons. At least given the failure in fact to accede to original intention with any consistency, it seems appropriate to dig deeper for some basis for a conclusion of authoritativeness.

so I will often refer to the constitutional "intenders" as if the summing problem had been overcome. I choose the term and slough over the summing problem in this way in part to emphasize the problems attached to an authoritative conception of original constitutional intentions even without considering that additional difficulty. 
even lack of foresight, that might seem an insufficient basis to deny authoritativeness to those intentions.

This first assumption can never be proved and seems highly questionable in the constitutional process where so many actors participate on behalf of so many legislative bodies ${ }^{61}$ and where those actors must accommodate to larger political realities. In such a situation, there is simply no telling whether political constraints on action, rather than accident or lack of foresight, led to some "intention" actually held by a coalition with the votes for passage being left unexpressed. Where the intention in question is focused more specifically than the language, it seems particularly likely that political opposition may have been defused (or may never have surfaced) because of the use of the more general language. Thus, the first assumption cannot plausibly ground the claim to constitutional authoritativeness of original intention.

The second assumption that may form the basis for the authority of intention is that, as expositors of an authoritative text, the intenders are entitled to have the interpreters of the text project their intentions over time. This assumption is normative, and, while hardly uncontroversial, it has some initial appeal. Taken seriously, however, this second assumption cannot carry the burden that originalists would assign it. The enterprise of projecting intentions or values through adjudications over time is very different from the enterprise of projecting the enacted language. A detailed appreciation of the problems in projecting values in the decision of particular problems through time is central to our inquiry into authoritativeness and into objectivity.

\section{Projecting Intention}

Before we consider the particular problems inherent in any attempt to project intentions through time, we must attend to the fact that an intention pretending to authoritativeness can be conceived at many different levels of generality or abstraction. If intention is conceived very abstractly, it can be treated as authoritative without seriously constraining judicial choice. Ronald Dworkin employs this approach, illustrating it with an example drawn from the history of fourteenth amendment jurisprudence. "Suppose," Dworkin writes,

a congressman votes for an amendment requiring "equal protection" because he believes that government should treat people as equals, and that this means not treating them differently with respect to their fundamental interests. He be-

s1 See Bennett, supra note 3, at 1090-91. 
lieves that the clause he votes for would be violated by criminal laws providing different penalties for blacks and whites guilty of the same crime, for example, because he believes that liability to punishment touches a fundamental interest. But he also believes that separate and unequal public schools would not violate the clause because he does not consider education to be a fundamental interest. ... [W] can distinguish an abstract and a concrete formulation of his intention. Under the former . . . if a court is itself convinced that education is (or perhaps has become) a fundamental interest, that court must believe it is serving his intention by outlawing segregation. ${ }^{\mathrm{B}}$

Originalists draw the same distinction but tend to stress the power of intentions conceived more specifically, because concrete intentions seem to bring with them more constraint on judicial choice. Monaghan, for instance, writes disparagingly that "academic lawyers . . . have sought to sterilize the concept [of original intent], most typically by conceptualizing original intent at a level of abstraction that, in effect, removes it as an interpretational constraint."53 Thus, for originalists, specific intentions are binding where they address a problem before the court, and resort to intentions conceived more abstractly is permissible (if at all) only in the absence of guidance from more focused intentions. ${ }^{54}$

Dworkin's insistence that intent can appropriately be conceived at a high level of generality is of a piece with his belief that constitutional law and moral philosophy are one. If intent is conceived abstractly, it can be treated as authoritative without allowing specific conclusions that come to be seen as immoral to get in the way. Whatever may be said of Dworkin's more general claim for the power of moral philosophy, however, he does not seem to have given original intent with regard to specific phenomena its due. At least he has not if intent is to

s2 Dworkin, supra note 4, at 489.

ss Monaghan, supra note 4 , at 378 .

st This is certainly the view of Raoul Berger. R. Berger, Government BY JUDICIARY (1977). More generally, originalists often seem confused about the proper level of generality at which intention is to be conceived. Bork, for instance, by virtue of a willingness to conceive of intention with a touch of generality, is able on occasion to tolerate constitutional outcomes contrary to what he sees as specifically intended. See Bork, supra note 8, at 14. At the same time, however, Bork asserts that if the constitutional history reveals a consensus, deviation from its "detailed choices" is not permissible. $I d$. at 13. Brest tellingly criticizes Bork for a failure to realize that his manipulation of the level of generality at which original intent is pegged itself reflects value choices. Brest, The Fundamental Rights Controversy: The Essential Contradictions of Nornative Constitutional Scholarship, 90 YALE L.J. 1063, 1090-92 (1981). 
maintain whatever claim to authoritativeness it has by virtue of its association with the intenders.

Dworkin's explanation of the role of abstract intentions suggests that two people could have the same abstract intention even though they would disagree on most applications of that intention. ${ }^{55}$ This is at best an awkward use of the notion of "intention," but if the abstract conception is used as the "intention," it should be recognized that it is an intention divorced from many values that were important to the intenders. ${ }^{58}$ This abstraction of the intention from the intender separates intention from the source that gives it its only plausible claim to authoritativeness.

In this respect the originalist seems right to insist on specific intentions as having the higher claim to authoritativeness when they are known. The originalist, however, seems wrong in any belief that knowing specific intentions allows one to project the intenders' values or process of decision over time, even as applied to phenomena very similar to the subjects of the specific intentions.

Constitutional questions come to court as claims that a particular state of affairs offends a constitutional norm. It is open to plaintiff and defendant to urge facts as relevant with any degree of specificity they desire. The litigants will thus always have available some way to distinguish their case from any case the intenders had in mind. Time will have altered some feature of any state of affairs specifically intended to be reached, or it will have fleshed out the features of any set of circumstances intended to be reached more generally.

We do recognize the continuity of phenomena through time. It

ss Dworkin does not explicitly say this, but his discussion at least leaves the possibility open. In his well-known example of a parent enjoining his children to be "fair," Dworkin suggests that the parent might tolerate his children reaching different conclusions than he does about what is fair because the child might be able to "convince" the parent. R. DwORKIN, supra note 12, at 134. Shortly thereafter, however, Dworkin makes clear that agreement on the general notion ("the concept") of fairness is compatible with very substantial divergence on particular applications ("conceptions"), apparently even after attempts at persuasion. Id. at 134-35.

Dworkin denies that the choice of the level at which to conceive intention can "be made by any further reflection about what an intention really is. It must be made by deciding that one rather than the other description is more appropriate in virtue of the best theory of representative democracy or on some other openly political ground." Dworkin, Law as Interpretation, 60 TEx. L. REv. 527, 547 (1982) [hereinafter cited as Dworkin, Law]. In a different article, he insists that the choice of the level of abstraction at which to conceive intention is "not a matter of finding which of the two intentions a particular Framer had; he had them both." Dworkin, supra note 4, at 497. In this way Dworkin attempts to make use of the authoritative appeal of intention to justify conclusions contrary to what he acknowledges might have been intended. See, e.g., id. at 499; see also R. DwoRKIN, supra note 12, at 136.

Bo See Sandalow, supra note 31, at 1046. 
seems reasonably clear, for instance, that those who enacted the fourteenth amendment identified the black $\operatorname{codes}^{67}$ as phenomena they intended by the amendment to forbid. If the question of the constitutionality of one of the black codes specifically intended to be forbidden came before the court, it might seem appropriate to claim an unequivocal "intention" to forbid it. ${ }^{\text {s }}$

Once we leave the province of continuing phenomena, however, complications emerge in using the notion of intention to reach phenomena that are necessarily distinguishable from anything the intenders had in mind. To be sure, if there was a conscious intention to reach a class of phenomena, then there was in a real sense an intention to reach every member of the class, even though members of a class differ from each other. Even a specific intention focused on particular phenomena may be conceived as reaching other phenomena that one concludes are effectively indistinguishable. In either case, however, a conclusion of the fit between the intention and the problem at hand will depend upon judgments about values.

Our legal system presumably could not countenance a constitutional order in which an Alabama statute passed before the fourteenth amendment would be unconstitutional but an identically worded (and similarly motivated) Mississippi statute passed after ratification would not be. Like cases are to be decided alike. But the two statutes differ; they were passed at different times, in different states. Thus, the judgment of "likeness" can be made only after a decision that the differences do not matter. ${ }^{\text {s0 }}$ The Mississippi statute case is an easy one, not because no values inform the judgment, but because we cannot reasonably conceive of any values that might identify the differences between the two statutes as relevant. If the conclusion is expressed in terms of "intentions," that is presumably a way of ascribing the value judgment

${ }^{57}$ Black codes in southern states relegated recently freed slaves to a position hardly better than their position as slaves, making them a socially, economically, and politically oppressed class. See 1 Documentary History of Reconstruction 273312 (W. Fleming ed. 1966); see also 1 Documents of AMERICAN History 452-57 (H. Commager ed. 1963). For example, a Mississippi vagrancy law severely limited freed slaves' movement. 1865 Miss. Laws 90, 91. The black codes were read and discussed in the congressional debates leading to passage of the fourteenth amendment. See, e.g., ConG. Globe, 39th Cong., 1st Sess. 443-44 (1866). Scholars have recognized that abolition of the black codes was a specific purpose of the fourteenth amendment. See, e.g., C. Antieau, The Original Understanding of the Fourteenth Amendment 70-72 (1981); J. TenBroek, The ANTislavery Origins of the FourteEnTH AMENDMENT 163-64, 168-69, 178-79 (1959).

68 But $c$ f. Bennett, supra note 3, at 1074 (discussing possible relevance of a "purpose" for not repealing a statute). (1982).

so See generally Westen, The Empty Idea of Equality, 95 HaRv. L. REv. 537 
to the intenders, either as a feature of a general intention to reach a class of phenomena or as a value held in addition to an intention held with specificity. As long as we can comfortably ascribe the value judgment to the intenders, we might discern an authoritative "intention" to prohibit the Mississippi statute. We are satisfied that it is unconstitutional because the question of relevant differences is so trivial. There are none. Once we confront the complexity in real life judgments, however, where sophisticated political actors define the substance of constitutional cases, it becomes much more difficult to ascribe a decision to the constitutional intenders in this way and hence invoke their authority.

The problem of projecting intenders' values through time is discussed in various legal contexts in terms of a hypothetical question of how the intenders would have dealt with a question they did not actually confront. ${ }^{60}$ That way of characterizing the process is probably chosen because it insinuates the authoritativeness of the answer. If we take the hypothetical intention device seriously, however, we can see the complications in the projection of intentions or values through time.

\section{Intentions and the Adjudicatory Process}

\section{Hypothetical Intentions: A Contract Example}

Let us begin our examination of hypothetical intentions with a simple case drawn from the lessons of the first-year contracts class. Early in their legal education, contracts students encounter the distinction between promises implied "in fact" and promises implied "in law." "61 As a part of that lesson, they must ponder the role of an individual's intentions and the possibility that the hypothetical intention device may be necessary to bridge a gap between actual implied promises and fictional "promises" the law imposes regardless of intention.

Consider the case of a regular customer of a dry cleaning establishment who has left the store after greeting the cleaner and leaving some clothes on the store counter to be cleaned. Contracts students soon become comfortable with ascribing an actual intention to pay for cleaning the clothes even though the customer said nothing about payment or even about cleaning. This conclusion is possible even though the customer may never have consciously considered the payment question. $\mathrm{He}$ was so used to transactions of this sort that we can perhaps assume an

${ }^{60}$ For example, Grano refers to what "the framers . . . perhaps would have intended." See Grano, supra note 5, at 67. 1981).

${ }^{31}$ See L. Fuller \& M. Eisenberg, Basic Contract Law 295-98 (4th ed. 
actual "intention" to pay, just below the level of conscious consideration. ${ }^{\mathbf{6 2}}$

But what if one of the garments the customer brought in was a recently acquired one that was made of some newly developed fiber requiring special procedures for cleaning? To eliminate the problem of two parties to a contract having different understandings of their "agreement," let us assume that the cleaner had not previously confronted the cleaning problem for the new fabric. After consideration, the cleaner's charge for the garment would, let us assume, be ten times the usual charge for cleaning conventional garments of this size and shape ( $\$ 20.00$ instead of the usual $\$ 2.00$, for instance). The customer, however, left the shop in ignorance of all this. What are we to say about the customer's intention to pay the higher price for the cleaning of this garment? The cleaner might reasonably think that in order to determine whether she should clean the garment, she must answer this inescapably hypothetical question.

The cleaner could attempt to answer the cleaning question in terms of an actual-quite specific-intention. The customer, we have supposed, intended to pay for this garment in the same way he intended to pay for the cleaning of the other clothes he brought in. This fact, however, does not help the cleaner who must decide whether to clean the garment. The cleaner is interested in whether the customer wants the garment cleaned at the higher price to be charged, and as to that question, the customer had no actual intention, conscious or subconscious. Even though it was focused as specifically as could be expected at the time, the actual intention the customer harbored did not address the problem specifically enough to resolve the question that has come to engage the cleaner.

The contracts students learn that they have now left the province of contracts implied in fact but have not clearly entered that of contracts implied in law. For a contract implied in law, the relevant question is not whether the customer intended to pay for the cleaning even though he didn't say so, but whether he should in justice be made to pay if the

${ }^{62}$ This example, of course, occurs in a context where there is no authoritative text. Authors' intentions in the use of a canonical text may have some features that distinguish them from intentions in contexts like the dry cleaning example. Some of the literature on originalism, for instance, discusses the relevance of "interpretive intent." See, e.g., Brest, supra note 3, at 215-16. Originalists themselves typically disdain any special features of intentions in the use of governing texts, see supra note 4, perhaps because no emphasis on the author's intentions about how the constitutional text is to be interpreted is likely to accord special status to their substantive intentions. See id. In any case, the questions I am about to raise in the text seem equally applicable to intentions harbored in the promulgation of a governing text. 
cleaner goes ahead and cleans it. The question here is not a pure one of a duty to pay implied in law. Answering the hypothetical question whether the customer would have wanted the garment cleaned at the higher price seems like an attractive way to answer the question of liability, and that hypothetical question inquires to a degree into the customer's state of mind. The cleaner does have some knowledge about the customer's values that provides a starting point in fathoming his hypothetical intention. She knows that, at his accustomed cost for cleaning garments of this size and shape, this one was too soiled for him.

The cleaner could say with virtual certainty that the customer would have wanted a garment cleaned if the charge were to be less than the usual charge. That judgment could plausibly be ascribed to the customer by the cleaner on the basis of the cleaner's general understanding of human values in the social environment in which both cleaner and customer function. The hypothetical question the cleaner actually faces, however, is unanswerable by reference solely to what she knows of the customer's values.

The cleaner's dilemma is similar to that of the constitutional interpreter. Originalists sometimes suggest that the only decision of unconstitutionality the interpreter can justify is one that clearly follows from specific original intentions, that is, one comparable to the cleaner's deciding to clean a garment for less than the usual charge. ${ }^{63}$ For the cleaner, however, such a view would require a decision not to clean more expensive garments, because no specific intention of the customer authorizes it. Yet no such restriction is permissible in the name of the customer's values or intention, for the customer might well have wanted to have the garment cleaned at the higher price. In similar fashion, if a court refuses to hold some state action unconstitutional because no focused original understanding that it would be unconstitutional can be found, that conclusion might be justified on the basis of a presumption in favor of "majoritarian" decisions but not, save in trivial cases, on the unaided basis of original values or intention. ${ }^{64}$

The lessons of the dry cleaning example run deeper. To see this, let us imagine some thinking the customer might have done about whether to have the troublesome garment cleaned. The decision might have been influenced by the intended use for the garment. Was it a special occasion or a routine one? The customer may have attached different values to having freshly cleaned clothes at the one or the other.

6s See Van Alstyne, Interpreting This Constitution: The Unhelpful Contributions of Special Theories of Judicial Revieu', 35 U. FLA. L. REv. 209 (1983); see also R. Berger, supra note 5, passim; cf. M. PerRy, supra note 15, at 74.

64 See, e.g., M. PERRY, supra note 15, at 34-35. 
The decision might further have been influenced by the alternative pieces of apparel the customer had available, and his feelings about the suitability of them for his intended use. It may also have been influenced by the alternative means available to clean or press the garment. It is perhaps natural to assume that the customer would readily have reached a decision if the question were put to him. For a variety of reasons, however, he might have found the question a difficult one. He might, for instance, have purchased four garments like the troublesome one, so that consideration of whether to have the one cleaned would have forced him to confront the possibility of consistently high cleaning bills. He may have intended to use the garment for a formal affair, and he may have had neither a good substitute nor an alternative way to clean the garment, but that might have led him to reconsider whether he would attend the formal affair rather than forcing him into a decision in favor of cleaning. In this way, values about matters beyond the immediate transaction in question might have affected his decision.

It is even possible that consideration of cleaning this difficult garment would have caused the customer to reconsider the value of having his clothes dry cleaned more generally. If he concluded that he could defer the cleaning of this garment because it wasn't all that soiled, perhaps that would have prompted him to think that he could tolerate a longer interval in having other clothes commercially cleaned. The process of considering this new question, that is, might have shed new light on other questions and might even have caused the customer to change conclusions previously reached.

The lesson of this example for the application of intentions is clear. Not only are we unsure about the customer's answer to the hypothetical question, but the answer might draw on considerations that even the customer did not consider relevant before they were brought to his attention by the process of considering the question. That process could cause the customer to emerge with different "values" than those he brought to the question, at least as those values are exemplified in his concrete resolution of life's decisions.

\section{Hypothetical Intentions in the Constitutional Context}

The constitutional interpreter faces problems comparable to those of the dry cleaner in attempting to project the intenders' values to new cases as they arise. Yick Wo v. Hopkins, ${ }^{\mathrm{BS}}$ an early case decided under the equal protection clause, provides an excellent example. In Yick Wo, 
the plaintiffs were resident Chinese aliens who complained about the administration of a San Francisco licensing ordinance in a manner calculated to keep Yick Wo and others out of the laundry business. The Supreme Court held that the discriminatory administration of the ordinance violated the equal protection clause of the fourteenth amendment, and that holding is generally approved by originalists. ${ }^{66}$ The draftsmen of the fourteenth amendment, however, were concerned about the problem of the newly freed slaves, and in particular about a number of state statutes disadvantaging them; some even excluded the freed slaves from certain occupations. $^{\theta 7}$ The Court could no more decide the issue in Yick Wo by exclusive reference to what it knew of the values or intentions of the constitutional intenders ${ }^{68}$ than our cleaner could have decided to clean the garment by reference to what she knew of the customer's values.

The problem presented by Yick Wo differs from any subject of original intention in a number of ways. Perhaps the applicability of the fourteenth amendment to discriminatory administration as well as explicit statutory discrimination would be an easy step, like passing from an Alabama statute to an identically worded Mississippi one. Arguably, there is no value the intenders might plausibly have held that would have caused them to resist this step. Indeed, it may seem that discriminatory administration is, if different in any relevant way at all, more offensive than facial discrimination. ${ }^{68}$

68 Monaghan hints at agreement with Yick Wo. See Monaghan, supra note 4, at $364 \&$ n.75. Grano is not explicit, but his discussion of the process of analogizing in constitutional law strongly suggests that he would find the decision acceptable. See Grano, supra note 5, at 61-75. Similarly, Bork's general discussion suggests agreement; moreover, he sets out a selection of cases he thinks offensive, and Yick Wo is not among them. See Bork, supra note 8, at 12.

67 See, e.g., Civil Rights and the American Negro: A Documentary HisTORY 223-24 (A. Blaustein \& R. Zangrando eds. 1968) (reprinting South Garolina Black Code, Dec. 21, 1865, 1865 S.C. Acts 291, 299 ("No person of color shall pursue or practice the art, trade or business of an artisan, mechanic or shop-keeper, or any other trade, employment or business [without a license which must be renewed annually and is subject to revocation."')); see also T. WILSON, THE Black CoDEs OF THE South 75, 79-80, 107-11 (1965) (describing restrictions on employment in various black codes).

${ }^{68}$ In the congressional debates on the fourteenth amendment there were some isolated (at times unflattering) references to the Chinese, see, e.g., ThE RECONSTRuCTion Amendments' Debates 152 (A. Avins ed. 1967) (remarks of Congressman Higby); id. at 224-25 (remarks of Senator Conness), but nothing approaching a defined position on the effect of the amendment on the status of Chinese or of aliens. The Court's decision in Yick Wo includes no reference to the debates or other legislative history.

${ }^{60}$ If Yick Wo seems an easy case-an obviously correct decision-it is probably because the offensiveness of the discriminatory administration overwhelms other considerations. Compare Yick Wo (administrative scheme held unconstitutional) with, e.g., Ambach v. Norwick, 441 U.S. 68 (1979) (upholding New York statutory restriction on 
A hypothetical intention to reach local ordinances as well as state statutes would start to be a good deal more problematic, given the importance attached in our political culture to the level of government at which some action is taken. It is clear, however, that we are right in the middle of a hypothetical intention stew when we consider whether the intenders would have decided to reach discrimination against resident Chinese aliens.

There is in the history of the fourteenth amendment much mention of racial discrimination as the problem being addressed, ${ }^{70}$ but even that doesn't help us much in applying the intenders' values. It does not take account of the details that would actually inform judgment. Yick Wo was distinguished not only by his race, but also by his alienage. As the Supreme Court's fits and starts over the years on the constitutional status of aliens demonstrate, ${ }^{71}$ the value judgments motivating prohibition of racial discrimination need not lead to the disapproval of discrimination against aliens. In particular, the Court has upheld several legislative restrictions on the employment opportunities of aliens that would clearly be impermissible as applied to black citizens of the United States. ${ }^{72}$ In the absence of any substantial attention in the fourteenth amendment debates to the question of aliens, there was no way to answer the hypothetical question by reference solely to what the Court could know with any confidence about the intenders' values. Indeed, as suggested by the dry cleaning example, even such explicit attention would not necessarily tell us how the intenders would have decided many actual problems regarding aliens that might arise.

noncitizens holding certain jobs). If that is so, it simply reinforces the point to be made in the text that each decision can open the way to a new future.

${ }^{70}$ See, e.g., Bickel, supra note 4, at 46, 48 n.92, 51-53; cf. id. at 22-24 (remarks of John Bingham, draftsman of the equal protection clause, during the debate on the Civil Rights Bill of 1866).

71 The shifting sentiments can be gleaned from Ambach v. Norwick, 441 U.S. 68 (1979) (upholding a New York statute forbidding permanent certification of aliens as public school teachers); Graham v. Richardson, 403 U.S. 365 (1971) (holding that Arizona and Pennsylvania statutes which denied welfare benefits to resident aliens or to aliens who had not resided in the United States for a specified number of years violated the equal protection clause); Ohio ex rel. Clarke v. Deckebach, 274 U.S. 392 (1927) (upholding a Cincinnati ordinance which prohibited the issuance to aliens of licenses to operate pool and billiard rooms); Truax v. Raich, 239 U.S. 33 (1915) (holding that an Arizona statute limiting the percentage of aliens employers could employ violated the equal protection clause).

${ }_{72}$ See, e.g., Foley v. Connelie, 435 U.S. 291 (1978) (upholding a New York statute which prohibited appointment of aliens to the state police force); Ohio ex rel. Clarke v. Deckebach, 274 U.S. 392 (1927) (upholding a Cincinnati ordinance which prohibited the issuance to aliens of licenses to operate pool and billiard rooms); Heim v. McCall, 239 U.S. 175 (1915) (upholding a New York statute which prohibited the employment of aliens on public works). 
Furthermore, if the constitutional intenders had decided Yick Wo, they would then have been differently situated for the next case. They presumably would want to decide like cases alike, judging likeness by their own system of values; but there is no reason to think that the relationship of likeness or analogy is transitive, so that Yick Wo (or any nontrivial elaboration of what has gone before) opens up for the decider the possibility of analogies not available before it is decided. If the case after Yick Wo, for instance, raised the question whether migrants from one state within the United States to another are within the protection of the fourteenth amendment, intenders who had decided Yick Wo might have been able to see those migrants as akin to aliens in a way that they could not be seen as akin to the freed slaves, when decisions about the latter were the only ones the intenders had behind them. ${ }^{73}$

There is, of course, no reason in theory why both steps of a twostep process of analogizing could not be taken in the decision of a single case. If the problem of interstate migrants were to arise before that of resident aliens, the intenders charged with the decision could decide with the mediation of a decision on the resident alien question they hypothesized for themselves. Despite the theoretical availability of any necessary intermediate steps, however, the actual decision of cases will be of much more significance as a bridge to new decisions than will hypothetical ones. The actual decision focuses the mind, and that in turn provides added confidence in the result. Moreover, the finality of an actual decision allows one to proceed to the next decision without constant temptation to look back.

Even more fundamentally, as we saw with respect to the dry cleaning example, the intenders might have emerged from deciding Yick Wo with a different configuration of values than those they brought to its consideration. To decide Yick Wo, the intenders would have had to think about aliens, and if they had a strong intuitive sense that Yick Wo had been wronged, they would have had to consider their values to determine exactly why. In the process, they might have been led to think not only about Chinese aliens, but about other alien groups as well. They might have thought about the number of aliens in different groups, about the costs and benefits they brought to the society, about the process by which aliens become citizens, and perhaps about the effect that treatment of aliens might have on the aliens or their children if they were to become citizens. The intenders might have been led by the alien question to consider the problem of the treatment of strangers in a

73 See Shapiro v. Thompson, 394 U.S. 618 (1969). Indeed, Yick Wo could open one's mind to the possibility of viewing all persistent political minorities as a bit like aliens among us. 
society more generally. In the process, the constitutional intenders might have developed fresh views not only on the subject of aliens, but also on the subject of the freed slaves with which they had originally been primarily concerned. They might, for instance, have come to see the problem of the freed slaves as stemming more from political helplessness than from their history of enslavement.

The constitutional intenders, of course, could not adjudicate Yick Wo's grievance or those that followed it. The dry cleaner may try to telephone the customer or take a chance and wait until he next comes in, but the court must decide for itself, at least once Marbury $v$. Madison ${ }^{74}$ is accepted as the law of the land. If original intent comes cloaked with the authority of the text, it apparently does so by virtue of its association with the intenders. That association, however, prevents intent from constraining decisionmaking authoritatively in the way the originalist seems to demand. Even if we knew all the values the intenders consciously held before they encountered a constitutional case, that would not tell us how those intenders would have decided a case differing in nontrivial ways from ones they had actually considered; nor would it tell us the values they would have held after the decision. Only the process of decision can elicit and shape the relevant values, and only the interpreters-successive courts-go through that process. ${ }^{75}$ Over time, those courts could reach conclusions that seem diametrically opposed to the intenders' initial ones without being untrue to "original intentions" in the sense that those intentions would have informed the intenders' decisions had the decisions been theirs to make. ${ }^{76}$

\section{The Failure of Authoritative Original Intention}

The argument in this part has taken the form of an internal criticism of originalism. By taking seriously its own insistence on the authority of original intentions, I have shown that assumptions about the constraining effect of those intentions are unsupported.

745 U.S. (1 Cranch) 137 (1803). Marbury laid the groundwork for the system of judicial review we have become accustomed to in the United States, but was by no means a foregone conclusion from the terms of the Constitution. See L. TRIBE, AMERICan Constitutional Law \$§ 3-1 to 3-5, at 20-33. According to Marbury the Court has a duty independently to interpret and apply the Constitution as law. See 5 U.S. (1 Cranch) at 177; L. TRIBE, supra, § 3-2, at 20-22.

${ }^{75}$ For a general discussion of the process of decision through which values are elicited and defined, see Spann, Expository Justice, 131 U. PA. L. REV. 585, 597-602 (1983).

${ }^{76}$ Cf. Sandalow, supra note 31, at 1064 (describing how the understanding of the specific intentions of the framers by subsequent generations "is necessarily conditioned by concepts with which the latter are familiar but that were unknown to the framers"). 
Dworkin is correct in his conclusion that the constitutional interpreter would not be authoritatively bound by a specific original intention to permit segregated schools, ${ }^{77}$ but he reaches this conclusion for the wrong reason. Separating levels of generality of intention, as Dworkin urges, drains the life from the abstractly conceived intention. Dworkin's conclusion is right because intentions and values are constantly being shaped and altered in their application to specific situations. In the adjudicatory process they are used in decisions. Only the interpreters are around to make the decisions, and even if they do so as best they can in the place of the constitutional intenders, deciding from that posture does not carry with it any assumption that the intenders' conclusions would have been unaffected by decisions made in the meantime under the authority of the language they enacted.

If originalists are to appeal to the authoritativeness of original intention, therefore, they must find a different route to authoritative intention-based answers. The only such route suggested in originalist literature, however, is not taken seriously even by originalists.

As noted above, ${ }^{78}$ originalists sometimes write as if, absent a specific original intention to the contrary, there is a conclusive presumption that a governmental decision is constitutional. Monaghan, for instance, endorses a description of originalism that, in Michael Perry's words, holds unconstitutional only "practices different in no significant respect from those the Framers banned."79 This position, however, is unpalatable; it would trivialize the law's requirement that like cases be decided alike, by forbidding a finding of "likeness" even in many cases where the constitutional intenders would have found it-and found it with ease. It is, for instance, not at all clear that the black descendants of freed slaves differ "in no significant respect" from the former slaves who were the focused subject of original fourteenth amendment intentions, yet I know of no suggestion in the literature that the fourteenth amendment must pass into disuse when the last ex-slave dies. When originalists do suggest their views on specific cases like Yick Wo, they seldom display fidelity to such a crabbed view of the power of original intent. ${ }^{80}$ This extreme view, indeed, is inconsistent with the basic premise of originalism; the use it seeks to make of original intent is di-

77 See supra text accompanying notes 52-55.

78 See supra text accompanying note 63.

70 Perry, Interpretivisin, Freedom of Expression, and Equal Protection, 42 Онго ST. L.J. 261, 281 (1981). See also Monaghan, supra note 4, at 360 n.54; Van Alstyne, supra note 63 , at $225-32$.

8o See supra note 66; see also Trimble v. Gordon, 430 U.S. 762, 777 (1977) (Rehnquist, J., dissenting); Rehnquist, The Notion of a Living Constitution, 54 TEx. L. REv. 693 (1976). 
vorced from the use that the intenders would have made of their own intentions. Thus, it uproots those intentions from the soil on which their claim to authoritativeness appears to feed. ${ }^{81}$

Sophisticated judges in a mature adjudicatory system must see all this. If courts in constitutional cases conceive of their task as deciding cases as the constitutional intenders would have decided them, at some point they must lose the trail. Even if judges can discover an opinion on a question before them that was held by the constitutional intenders, they still cannot know how bearing the burden of decisionmaking over the years might have affected the intenders' judgment. More important, over the years the judicial process will have given birth to an everexpanding body of decisions, the ancestry but not much of the content of which will be traceable to original intentions. Judges can feel bound by enacted language, but if the language is too general to constrain by itself, most of what has been done in its name has been produced by people just like them. Judges cannot know whether the framers would have changed their minds on any given issue; over time the process of resolving issues on the basis of the framers' hypothetical intentions becomes effectively no different from the process of deciding issues on the basis of judicial experience. It follows that the important question for judges interpreting open-ended constitutional language that has been applied over the years to a variety of situations is not whether there is some decision that they are authoritatively obliged to make. The important question is what conception they have of the proper role of a member of the judiciary. Part of such a conception is an account of the extent to which they should accept constraints on their own set of choices for reasons other than the authoritativeness behind the constraint. In part III, I will turn to the nature and mechanisms of such constraints.

\section{The Extent of Objectivity}

The search for constitutional authoritativeness is motivated, at

81 Originalists also abandon their basic premise at times in another way. They sometimes endorse various judge-made standards as authoritative. This may, for instance, be what Bork had in mind in his call for "a valid theory, derived from the Constitution." Bork, supra note 8 , at 3 . Such a move compromises the originalist claim that only the language of the Constitution interpreted in light of the framers' intentions is authoritative.

Once originalism is abandoned judge-made standards may play a decisional role as an objective source of values. Thus, Herbert Wechsler's classic article, Toward Neutral Principles of Constitutional Law, 73 HARv. L. REv. 1 (1959), urged that adherence by judges to judicially crafted standards was the essence of the rule of law, but Wechsler was no originalist. See id. at 15. 
least in part, by a concern that the judicial office not be the vehicle for the exercise of personal power. As we saw in part II, originalism, the most promising source for constitutional authoritativeness, cannot simultaneously retain its authoritativeness and its capacity to provide significant constraints on judicial choice. In this part I will show how decisionmaking, nonetheless, may be conceived as "objective" without necessarily being obedient to authority.

First, I will discuss in general how judicial behavior is characterized by a large measure of objectivity. I will then consider the three most prominent external sources on which judges appear to draw: original intentions, judicial precedents, and the decisions of other branches of government which courts review. These sources do not collectively define the resources of judicial objectivity; they are important sources but not the only ones. Their importance suggests an organic view of the development of judicially endorsed values. The legitimacy or objectivity of a decision has to do more with its development from a preexisting tradition and natural growth from an institutional soil than with its approval by authority. This conception of objectivity explains the kind of constraint on arbitrary judicial power that is, in fact, generally accepted by judges; it produces real constraint on judicial choice while allowing growth in the law, and, in any event, it is the only form of check on judicial interpretation of broad constitutional language we can realistically hope to achieve.

The account I will suggest does not provide an unequivocal basis for evaluating decisions; it is an account of influence but not of a line between right and wrong answers. It is from this point that I will return to Dworkin's position. He suggests that a truly objective judge could limit the range of possible decisions down to one, the right one. Dworkin's rehabilitation of constitutional authoritativeness seems, at best, premature. I will conclude this part with an explanation of why judicial objectivity should not, at least right now, be grounded in an appeal to the authority of moral philosophy.

\section{A. Judicial Objectivity}

Constitutional jurisprudence is suffused with an insistence that the choices judges make are not personal. The interpretations judges announce are said to emanate from the Constitution ${ }^{82}$ or from the intentions of the framers. ${ }^{83}$ Deference is owed to the judgment of the legisla-

${ }_{82}$ See, e.g., United States v. Butler, 297 U.S. 1, 62 (1936).

ss See, e.g., Scott v. Sandford, 60 U.S. (19 How.) 393, 425-26 (1857); see also Home Bldg. \& Loan Assoc. v. Blaisdell, 290 U.S. 398, 453 (1934) (Sutherland, J., 
ture, which is viewed as the proper place in the governmental process for making value judgments. ${ }^{84}$ The pervasive form of justification in constitutional opinions - as in other areas of the law-is argumentation from judicial precedent, as if the Court's conclusions were dictated by those precedents.

Some of the great battles in the history of constitutional jurisprudence have been waged-sometimes on both sides-in the name of constraint on arbitrary or personal judicial choices. Those who favored incorporating the limitations of the Bill of Rights into the fourteenth amendment, for instance, argued that incorporation would bring constraint to an otherwise open-ended text. ${ }^{85}$ Among the opponents of incorporation, judges known for their sense of restraint argued that it was desirable to leave legislatures free of some of the less important strictures of the Bill of Rights. ${ }^{86}$

Of course, no one takes seriously protestations of objectivity in the extreme form sometimes found in court opinions. Even without the tradition of dissents, it would be clear that important value choices were being made under the cover of judicial objectivity. Part of the doubt about judicial objectivity may be a product of the fact that courts protest too much. ${ }^{87}$

At the same time, the suggestion that judges in deciding cases pursuant to open-ended constitutional text are simply deciding on the basis of "personal" preferences cannot be taken seriously. Judges understand that, in their role as judges, certain "personal" bases of decisions are foreclosed. Judges, for instance, are forbidden by tradition as well as by law from adjudicating cases in which their material interests or those of their relatives are involved. ${ }^{88}$ In marginal cases, as for instance where a personal friend is the lawyer for one of the parties, the judge is to decide the matter without consideration of that fact. Judges who believe they cannot decide free from such considerations have a duty to recuse themselves. Although judges may occasionally violate these restrictions, they appear to be generally observed. We seem to doubt neither judges' ability to exclude "personal" bases of decision in this sense, nor their

dissenting).

84 See, e.g., Dandridge v. Williams, 397 U.S. 471, 486-87 (1970).

ss See Adamson v. California, 332 U.S. 46, 71-75 (1947) (Black, J., dissenting).

${ }^{88}$ See, e.g., id. at 61-67 (Frankfurter, J., concurring).

87 Kent Greenawalt has an interesting discussion of the judicial practice of writing opinions as if the conclusion reached were unarguable. Greenawalt, Discretion and Judicial Decision: The Elusive Quest for the Fetters That Bind Judges, 75 Colvm. L. REv. 359, 383-85 (1975).

${ }^{88}$ See 28 U.S.C. $\S 455$ (1976 \& Supp. V 1981); see also Tumey v. Ohio, 273 U.S. 510 (1927). 
willingness to do so.

Similarly, judges are not to decide on the basis of their personal reactions to the physical characteristics or to the personalities of lawyers or litigants. In social life, a judge may be drawn to humorous people or contemplative ones, to polite people or to redheads; but until such factors enter the realm of public policy, they are irrelevant to the judge's decision of a case. ${ }^{89}$ We have so little concern that judges will be tempted to employ "personal" values of this sort that we do not even formally prohibit them from considering such factors, as we prohibit their consideration of their own material interests and those of their relatives.

Judges do not make personal choices; they make choices about public values. That assumption is so much a part of the judicial role that commentators can charge judges with making "personal" decisions seemingly without appreciating that, in some core uses of the word "personal," the charge is obviously false."

Even if we confine our attention to the preferences of judges on matters of public policy that will vary from judge to judge, any conclusion that judges do not operate within externally defined constraints is inaccurate. Judicial nonobjectivity would presumably be a regime in which courts worked out for themselves $a b$ initio each issue of public policy to come before them. Probably no decisionmaking body does that, ${ }^{91}$ but it seems clear that the Supreme Court of the United States does it less than many others.

If we take legislative activity as the basis for comparison, the volume of legislative provisions held unconstitutional by courts must surely be a minuscule fraction of provisions passed by one house of a bicameral legislature but rejected by the other, passed by the legislature and vetoed by the executive, or proposed by the executive and rejected by the legislature. ${ }^{22}$ Perhaps the courts are never asked to consider most

89 See Greenawalt, supra note 87 , at 368-69.

so "Personal" means "[o]f, pertaining to, concerning, or affecting the individual person or self (as opposed, variously, to other persons, the general community, etc. or to one's office, rank, or other attributes); individual; private; one's own." VII THE OXFORD ENGLISH DICTIONARY 726 (1961).

91 "Continuity with the past, said Holmes, is not a duty; it is merely a necessity." A. Bickel, The Least Dangerous Branch 16 (1962).

92 It is very difficult to come up with precise figures for comparison, but I doubt that there will be much quarrel of a factual nature with the basic point. See Commager, Iudicial Review and Democracy, 19 VA. Q. REv. 417, 422-28 (1943); Levy, Judicial Review, History, and Democracy: An Introduction, in JudICIAL Review AND The Supreme Court 20-24 (L. Levy ed. 1967); see also Congressional Research Serv., Library of Congress, The Constitution of the United States of AMERICA: ANALYSIS AND INTERPRETATION 1595-1619 \& 1980 Supp. S305-08 (S. Doc. No. 82, 92nd Cong., 2d Sess. (1973) \& S. Doc. No. 64, 96th Cong., 2d Sess. 
legislation, but that only poses the question why not. There are "losers" in almost all legislative battles, but for the most part they do not go to court with a constitutional challenge. ${ }^{93}$ They do not do so, in part, because they know that such challenges will usually be met with a deaf judicial ear. The conclusions seems inevitable that judicial choice operates within a narrower compass than legislative choice. On more than one occasion the author of a Supreme Court opinion has made clear that the result in the case is not in accord with the views on public policy of one or more of the judges voting for it. ${ }^{94}$ The interesting question about judicial objectivity is not whether judges generally view their subjective preferences on matters of public policy as constrained; rather, the interesting questions concern the nature and extent of the external contribution to decisions and the mechanisms by which the contribution is achieved.

The role of judicial objectivity can best be appreciated, I think, by seeing constraint by objective sources as itself something valued by courts-as one ingredient in a complex mixture of values. Objectivity is a virtue of courts and not so much of legislatures because they have very different governmental roles to play. Judicial objectivity is symbolic of the judicial role. Judges use their discretion to resolve questions

(1982)) (listing acts of Congress held unconstitutional by the Supreme Court, numbering 105 as of 1980). More likely than a challenge to the truth of the assertion is a challenge to the relevance of the comparison. It might be argued, on the one hand, that the appropriate unit for measuring legislative opinion is the legislator or the committee. This would, of course, make the contrast with the judicial branch more stark. On the other hand, it might be urged that any comparison at all is inapt because legislatures are reacting to diverse constituent interests rather than expressing the public policy choices of their members. This latter criticism simply reinforces the point to be made in the text that the judiciary, like any institution, operates within and is necessarily a creature of an environment it does not entirely define. If any lingering doubt remains, I can only urge a thought experiment comparing the likely "personal" policy preferences of most judges in, say, Dandridge v. Williams, 397 U.S. 471 (1970), with the outcome in the case. See also authorities cited infra note 94.

${ }^{93}$ But see Davidson v. New Orleans, 96 U.S. 97, 104 (1878) ("[T] this Court is crowded with cases in which we are asked to hold that . . . State legislatures have deprived their own citizens of life, liberty or property without due process of law.").

of Some examples are collected in Reed, Stare Decisis in Constitutional Law, 1937-38 PA. B.A.Q. 131, 137 n.12; see also Kadish, Judicial Review in the United States Supreme Court and the High Court of Australia (pt. 2), 37 TEx. L. Rev. 133, $153 \mathrm{n} .84$ (1958) (expressing doubt that there are very many cases in which a justice votes for a position with which he "seriously disagrees"). For a recent example, see Harris v. McRae, 448 U.S. 297, 326 (1980) (stating that if it were the mission of the Court to decide whether providing federal funds for abortions is wise social policy, not every Justice who subscribed to the judgment would have done so); $c f$. Furman v. Georgia, 408 U.S. 238, 405 (1972) (Blackmun, J., dissenting) (stating his dissent from the Court's holding that imposition of the death penalty in the case would be unconstitutional despite his own "distaste, antipathy and indeed abhorrence for the death penalty"). 
of value, but those value judgments are a necessary byproduct of the primary judicial function of dispute resolution. ${ }^{95}$ Policy or value questions are affirmatively assigned elsewhere in the governmental structure-to legislatures, administrative agencies, and to the makers of constitutions. Judicial objectivity helps affirm that judicial value choices are an outgrowth of, but not the reason for, the judicial office.

There is no reason to believe that judges systematically value judicial objectivity less than other students and philosophers of the law. Perhaps some judges value the exercise of power for its own sake and for that reason are tempted to value objectivity less. Some judges probably do relish the power of the office or have such certainty of the rightness of their own views on public policy that they resist subordinating them to external forces. ${ }^{96}$ But the socialization process all judges go through stresses restraint, and the judicial office thus defined is one that commands respect. Judges therefore have an interest in reinforcing the aspects of their role that yield that respect, and it would seem that judicial objectivity is one of those aspects. ${ }^{87}$

The tradition of justification in the form of a judicial opinion is a primary mechanism of constraint, exposing judicial decisions to the discipline of reason and judicial reasoning to the judgment of the world. ${ }^{88}$ The persuasiveness of judicial opinions is, at least in part, a function of their effectiveness in marshaling arguments from objective sources of value, and those opinions suggest that three objective sources are of particular importance. I would like to concentrate here on the role of those three sources-original intentions, judicial precedents, and the governmental actions under review.

os For a contrary view, that dispute resolution is merely an incident of the primary judicial function of eliciting and defining values as they apply to social practice, see Spann, supra note 75, at 592-93. For a discussion of the more commonly held perception of the judicial function as primarily one of dispute resolution, see $i d$. at 58889. Despite his somewhat different viewpoint of the primary role of the judiciary, Spann argues that the judiciary must not engage in policymaking but instead must have external, objective bases for its decisions. See id. at 635-36.

98 Professor Easterbrook associates following precedent with the loss of "power." Easterbrook, supra note 24, at 822. (1983).

97 See Stevens, The Life Span of a Judge-Made Rule, 58 N.Y.U. L. REv. 1, 2

98 See Chemerinsky, Rationalizing the Abortion Debate: Legal Rhetoric and the Abortion Controversy, 31 Buffalo L. Rev. 107, 132 (1982); Freed, Polsby \& Spitzer, Unions, Fairness, and the Conundrums of Collective Choice, 56 S. CAL. L. REv. 461, 498-99 (1983). 


\section{B. Intention, Precedent, and Governmental Action}

\section{Intention, Precedent, and Institutional Continuity}

To a great extent, judges seem to view their task as projecting into the future what the work of their predecessors has delivered to them. In part II we considered a model of judicial decision under which the court conceived its task as deciding cases as the constitutional intenders would have decided them. ${ }^{98}$ We saw that unless the differences between the evils that concerned the intenders and a case before the court were of trivial significance, there would be no way for a court to decide solely on the basis of value judgments it could plausibly ascribe to the intenders. That conclusion does not imply, however, that such a conception of the court's task would have no influence on its decision. At least in the early cases decided under some governing provision, that conception would require the court at a minimum to take the original intentions of which it was aware as fixed points that its decision must initially accommodate. The Court that decided Yick Wo v. Hopkins ${ }^{100}$ could, if it conceived its task this way, take as given that freed slaves could not be denied certain jobs in the way San Francisco seemed bent on denying jobs to Chinese aliens. This would affect the decision it had to make, by giving it some objective moorings and judgments about some of the issues at stake. Similarly, the dry cleaner's question was given initial shape and direction by the fact that the customer had left the garment in the store to be cleaned.

The original intentions the early court could take as given might be little or no help. A court, for instance, might find original fourteenth amendment intentions about freed slaves uninstructive in dealing with a complaint by homosexuals of official harrassment. For a court that conceived its task as emulating the decisions that would have been made by the constitutional intenders, official harrassment of homosexuals would present a dilemma, if the intenders signaled nothing helpful at all on the matter. Such a court could decide on the basis of its considered sense of right and wrong or by deferring to some external source of substantive values, like that embodied in the official action under review.

For the purposes that concerned us in part II, we saw that, as successive courts decided cases further removed from the situation facing the intenders, it would become progressively less realistic to ascribe their judgments to those intenders. The contributions of earlier courts 
to the values embodied in the total corpus of decisions would be too apparent. It is striking nonetheless how much actual judicial use of original intentions and particularly of precedent resembles what might be expected if courts deciding constitutional cases continued to conceive their roles as emulating as best they could the decisions that the constitutional intenders would have reached.

Consider the part that original intentions and precedents would likely play if a single person first enacted some capacious constitutional text and then adjudicated a long series of cases pursuant to it. The adjudicator could be expected to strive to reconcile the various decisions to avoid cognitive dissonance. ${ }^{101} \mathrm{He}$ would feel a responsibility both to the substance of his prior decisions and to their articulated justification. ${ }^{102}$ But unless the adjudicator had a highly developed and coherent system of moral philosophy, extraordinary intellectual discipline in applying it, and unusual confidence both in its relevance and in its continued power over time, tensions and inconsistencies could be expected to emerge in the body of decisions. Some of the techniques that could be employed to deal with these decisions would be to point to "changed circumstances" since some earlier decision, and to reconcile two decisions by distinguishing their facts when one seemed inconsistent with the explanatory opinion accompanying another. When two precedents seemed to counsel opposite results in a particular case, and to do so with equal force, the adjudicator might be expected to defer to the more recent one. Abrupt repudiation of a prior decision would be rare; more typically, there would be a gradual process of erosion over time.

Each of these techniques is, of course, common in judicial use of precedent and of original intentions. ${ }^{103}$ The use of these techniques suggests that an "institutional dissonance" is at work; courts feel a responsibility for decisions of their predecessors akin to what a single intender-adjudicator might feel. The correlation between judicial behavior and what might plausibly be expected from the hypothetical individual is clearly imperfect. Even recent precedent is sometimes openly disdained, ${ }^{104}$ and at other times precedent is manipulated in a

101 See generally L. Festinger, A Theory of Cognitive Dissonance (1957). To a great extent, this discussion of the individual adjudicator is informed by my own experience as the neutral arbitrator in a series of disputes between two parties, pursuant to a single governing contract.

102 For this reason an adequate theory of precedent will treat both holding on the facts and rationale as part of what is precedent. This may also explain on a psychological level why there is an attempt to distinguish that part of the rationale treated as holding and that treated as dictum. Dictum is that part most easily rationalized away. ${ }_{103}$ See generally Israel, Gideon v. Wainwright: The "Art" of Overruling, 1963 SuP. CT. REV. 211.

${ }_{104}$ See, e.g., Ohio ex rel. Eaton v. Price, 364 U.S. 263, 269 (1960) (opinion of 
fashion that seems quite shameless. ${ }^{105}$ Nevertheless, the value placed on institutional continuity has a real effect on the substance of judicial decisions. ${ }^{108}$

A great deal of behavior by judges and others would be quite mysterious if the value judges place on institutional continuity is ignored. For example, litigants with interests in general issues that are likely to recur or that affect many persons frequently search for a particularly sympathetic case with which to pose the general issue to the court. This is done on the assumption that, if the court decides in their favor with general language, a later court will not ignore that language thereafter and simply seize upon the difference between the sympathetic situation and the next one to decide each as it would have in isolation from the other. ${ }^{107}$

Brennan, J., for four Justices) (stating that the Court would not be influenced by the judgment in Frank v. Maryland, 359 U.S. 360 (1959)); see also Monaghan, supra note 23, at 8-9 (discussion of the five-person majority in Lalli v. Lalli, 439 U.S. 259 (1978)).

${ }^{103}$ See, e.g., L. Fuller \& M. Eisenberg, Basic Contract Law 713-16 (4th ed. 1981) (discussing pattern of Supreme Court decisions on the use of summary process against allegedly delinquent consumers).

${ }_{106}$ See Stevens, supra note 97, at 4 ("The framework for most Court opinions is created by previously decided cases.").

The results of an empirical study of the authority cited in state supreme court cases support the conclusion that judges place a high value on institutional continuity. See Style and Citation, supra note 20. That study found that state supreme court cases cited to prior in-state opinions far more frequently than they cited out-of-state cases or federal cases, see id. at 796 \& figure A, and cited court opinions more frequently than they cited statutes and regulations, see $i d$. at 808 .

Dworkin writes that, in contrast to the legislator, the judge "will always try to connect the justification he provides for an original decision with decisions that other judges or officials have taken in the past." R. DwORKIN, supra note 12, at 112. Schauer emphasizes the greater importance of the recent past. See Schauer, supra note 1 , at 829.

107 The choice of individual class representatives with sympathetic factual situations in the several cases decided as Shapiro v. Thompson, 394 U.S. 618, 623-26 (1969) (invalidating denial of state welfare benefits to persons who had recently moved to the state), was, of course, no accident.

If precedent actually has little or no effect on judicial behavior, the various actors in the drama of constitutional adjudication appear to have been fooled en masse. Judicial precedents-fourteenth amendment ones included-are categorized, indexed, read, debated, and distinguished in ways and in a volume that is incredible if they play little or no role in the process of decision. There actually may be no contemporary commentators who doubt that precedent acts to a degree as a constraint on judicial decisions, constitutional decisions included. Henry Monaghan, for instance, has been particularly critical of the Supreme Court for its infidelity to stare decisis. See Monaghan, supra note 4, at 387-91. Monaghan's objection, however, does not seem to be that precedent fails to constrain at all, but only that it constrains too little. Id. One thing Monaghan says of original intent is even more clearly applicable to precedent: "Judicial opinions at least purport to take original intent seriously, apparently reflecting the belief that the original intent mode is not simply a matter of expository style in opinion writing." Id. at 375 (footnote omitted). Constraint by precedent will, however, often be more indeter- 
Concern with the continuity and integrity of the body of judicial decisions places an "external" constraint on judicial choices of public values. ${ }^{108}$ The operation of this institutional dissonance explains the importance of precedent, ${ }^{100}$ as well as the importance of original intentions. Like original intentions, however, precedent will not usually yield determinate answers to new questions that arise.

As we saw in our discussion of originalism, ${ }^{110}$ continuity with the past may not give determinate answers even to questions that are effectively indistinguishable from some that were previously answered. The receptivity of the adjudicatory process to plausible arguments on the basis of factual distinctions guarantees a steady flow of novel substantive questions. ${ }^{111}$ Social, political, and economic change probably assures the flow, but even if it did not, litigants would, as they adjust their activity and their tactics to take court decisions into account. The flow of novel questions allows continuity to accommodate movement and even on occasion an institutional change of mind.

Tension between the value attached to institutional continuity and to substantive values is inevitable, so that the extent to which precedent constrains will take-account of what else is at stake. Development in the law can be more or less continuous, and the value placed on continuity does not exclude other values. The tension typically surfaces when courts encounter cases that arguably differ from earlier ones in relevant ways but seem to be covered by rules of law and principles announced in the earlier cases. Such rules and principles constrain judicial choice just as the more specific constitutional language does. The

minate than Monaghan and other champions of stare decisis seem to assume.

${ }^{108}$ The metaphor of "constraint" may be unfortunate, for it suggests outer bounds for the choices available rather than mere influence on them. My suggestion that divergence from precedent may create institutional dissonance is intended to capture the fact of influence without imposition of outer boundaries. Dworkin's reference to the "gravitational force" of precedent.suggests the same point. See R. DwORKIN, supra note 12, at 112.

100 The doctrine of stare decisis is clearly functional in the legal system for reasons apart from the constraint it provides on decisions of courts of last resort. Respect for precedent allows judge-made law to provide guidance for primary conduct, and it helps inferior courts follow the will of superior ones, so that like cases are more likely to be decided alike within the judicial system. Stare decisis also provides an efficient route to resolution of problems that do not warrant de novo consideration. See Stevens, supra note 97 , at 2 . Lea Brilmayer even suggests that fidelity to precedent is necessary to allow courts to make enduring value choices. Brilmayer, The Jurisprudence of Article III: Perspectives on the "Case or Controversy" Requirement, 93 HARv. L. REv. 297, 304-05 (1979). For these reasons precedents would be prominent institutional data even without consideration of the issues with which I am concerned in this Article. These other institutional functions of precedent may explain why judges seem to turn to prior decisions so readily as a primary external source of values.

110 See supra text accompanying notes 56-76.

111 See Michelman, Constancy, supra note 25, at 414. 
extent of the constraint is a function of the specificity of the principles or rules and of the durability with which judges decide to invest them.

The English tradition at common law has been to adhere to judgemade rules with a high degree of fidelity. ${ }^{112}$ English-style deference will often mean the sacrifice of substantive values-those of the adjudicator to be sure, but even of those who decided the precedent to which deference is urged. The dry cleaner could abide by the "objective" indication she had of her customer's wishes (that is, leaving the garment in the shop) only at the risk of jeopardizing values of the customer that were not revealed by the objective signs. To take an example from contemporary constitutional law, it is not at all clear that holding affirmative action programs unconstitutional would serve the values of the judges who announced in earlier cases dealing with actions disfavoring racial minorities that discrimination on the basis of race was suspect or forbidden. ${ }^{113}$

The American tradition, both at common law and in the constitutional context, has been to accord judicially crafted standards considerably less deference than in England. ${ }^{114}$ The American tendency has been to hold judge-made law open to a continuing process of reexamination and to assess the sense the rules make for the case at hand as well as for those cases easily foreseen. ${ }^{115}$ The American tradition represents an inclination to compromise the value attached to institutional continuity with substantive values that inevitably intrude.

What is the right amount of respect for precedent is always a matter of degree and of judgment. The English tradition suggests one extreme, the American, perhaps, the other. Criticism of the American disrespect for precedent is common, and at least sometimes appropriate, since respect for precedent is a value that the adjudicatory system purports to embrace. ${ }^{116}$ What seems improper is criticism of a constitu-

112 Even in England, though, the treatment of precedent seems to be less deferential in recent years. See A. Cross, Precedent In ENGlish LAw 6-7 (2d ed. 1968).

11 See, e.g., Regents of the Univ. of Cal. v. Bakke, 438 U.S. 265, 292-93 (1978) (using language from Yick Wo v. Hopkins, 118 U.S. 356, 369 (1886), to strike down a particular affirmative action program).

114 A. CRoss, supra note 112, at 15.

118 See, e.g., Craig v. Boren, 429 U.S. 190 (1976) (heightening the standard of review in sex discrimination cases).

116 A recent article by Frank Easterbrook seems to argue that no value should be placed on respect for precedent. See Easterbrook, supra note 24. Easterbrook argues that the Supreme Court should not be bound by precedent because, if it is, the outcome of a case may in many (realistic) circumstances be dependent on the order in which prior relevant cases were decided. Id. at 814-23. He views this "path dependence" as intolerable, apparently because it would subvert the ability of judges to decide on the basis of their "first principles." Id. at 818-21. "The order of decisions," Easterbrook says, "has nothing to do with the intent of the framers or any of the other things that 
tional decision on the basis of either its substance or its disrespect for precedent without appreciation of the fact that both are valued determinants of judicial decisions. ${ }^{117}$

\section{Continuous and Discontinuous Development}

Judicial use of precedent and original intentions in the service of institutional continuity seldom, if ever, defines a single option for courts. Rather, it opens up possibilities for further steps in a developmental process.

Among contemporary decisions, Roe $v$. Wade $e^{118}$ is probably cited most frequently as an example of judicial imposition of values uninformed by objective sources. Roe $v$. Wade is high on John Hart Ely's list of offensive cases ${ }^{118}$ and on those of originalists. ${ }^{120}$ In both cases,

might inform constitutional interpretations." Id. at 820 .

"Path dependence" in this sense is, of course, the essence of respect for precedent. What Easterbrook misses is the fact that respect for precedent is itself a norm of judicial conduct, given far more service, by lip and probably by deed, than many of the other "first principles" he has in mind. Ironically, the "first principle" Easterbrook personally favors is originalism. Id. at $828 \mathrm{n} .57$. He provides no explanation why the respect for the past represented by originalism is more sensible a "first principle" than is respect for judicial precedent.

Easterbrook does not deny that constitutional law could proceed with substantial respect for precedent. $I d$. at $832 \mathrm{n} .63$. It is not even clear that he intends to deny that precedent plays a significant role in fact.

112 The internal contradictions of a decision or its failure otherwise to persuade are, of course, legitimate bases of criticism apart from either the substantive or precedential case that might have been advanced in support of it.

It is sometimes said that stare decisis has less force in constitutional law than in other contexts. E.g., Edelman v. Jordan, 415 U.S. 651, 671 (1974). In the words of Justice Brandeis:

[I]n cases involving the Federal Constitution, where correction through legislative action is practically impossible, this Court has often overruled its earlier decisions. The Court bows to the lessons of experience and the force of better reasoning, recognizing that the process of trial and error, so fruitful in the physical sciences, is appropriate also in the judicial function.

Burnet v. Coronado Oil \& Gas Co., 285 U.S. 393, 406-08 (1932) (Brandeis, J., dissenting). The oft-stated reason for this relaxed attitude toward the force of precedent is that only the judiciary can change the content of constitutional law when it is perceived as wrong. E.g., Graves v. New York ex rel. O'Keefe, 306 U.S. 466, 491-92 (1939) (Frankfurter, J., concurring). In terms of judicial objectivity, the point would be that in nonconstitutional contexts there are alternative outlets for the realization of substantive values that compete with the value attached to judicial objectivity. In the constitutional context, insistence on the extreme in objectivity by following precedential standards that counsel unconstitutionality virtually assures the sacrifice of other values. The same is not true, however, for precedent that leaves the political process unimpeded. The justification for the diminished strength of stare decisis is thus more clear when the precedent impedes legislative and other political action than when it does not.

118410 U.S. 113 (1973).

119 See Ely, The Wages of Crying Wolf: A Comment on Roe v. Wade, 82 Yale

L.J. 920 (1973).

120 See, e.g., Grano, supra note 5, at 8-9. 
however, the charge derives from a vision of constitutional authoritativeness with which Roe $v$. Wade is thought inconsistent. From the perspective of judicial objectivity, the decision is not so easy to criticize.

Roe v. Wade built on a series of prior decisions, some going back to much earlier courts, that protected the interests of adults with regard to procreation and those of parents with regard to children. It is plausible to see those prior decisions as opening a future that could accommodate Roe v. Wade. ${ }^{121}$ To be sure, Roe $v$. Wade did require a value judgment beyond those captured by prior decisions. In that respect, the case was no more unusual than Yick Wo or hundreds of other constitutional cases, except perhaps that the judgment required was a particularly wrenching one.

My point is not that Roe $v$. Wade was rightly decided, but that the debate about whether the Supreme Court could legitimately invalidate laws prohibiting abortion is often misconceived. Viewed as a question of judicial objectivity, the legitimacy of Roe $v$. Wade turns not on whether there is some authoritative basis on which the Court can substitute its value judgment for that of the legislature but on whether the Court can successfully define its opinion as a natural outgrowth of what it has received. Perhaps my judgment that substantial continuity was demonstrated in Roe $v$. Wade is wrong. The continuity inquiry is not one to which authoritative answers are available. The legitimacy of Roe v. Wade, however, should be debated in terms of institutional continuity and of its substantive merits and not by reference to one or another dubious and inevitably incomplete standard of authoritativeness.

In contrast to Roe $v$. Wade, the state legislative apportionment cases, favorites of Ely, ${ }^{122}$ seem much less justifiable in terms of institutional continuity. In Baker v. Carr, ${ }^{128}$ a case challenging the egregious malapportionment of the Tennessee legislature, the Supreme Court broke with precedent to find that questions of state legislative apportionment were justiciable. The Court reasoned in part that "judicially manageable standards"124 for reviewing legislative apportionment were available: "Judicial standards under the Equal Protection Clause are well developed and familiar, and it has been open to courts since the enactment of the Fourteenth Amendment to determine, if on the partic-

121 See Heymann \& Barzelay, The Forest and the Trees: Roe v. Wade and Its Critics, 53 B.U.L. REv. 765 (1973). I have argued elsewhere that the case can also be justified in terms of a constitutional antidote for imperfections in the political processes. See Bennett, supra note 48.

${ }^{122}$ See J. Ely, Distrust, supra note 2, at 120-25.

123369 U.S. 186 (1962).

124 Id. at 226. 
ular facts they must, that a discrimination reflects no policy, but simply arbitrary and capricious action."125

Two years later, in Reynolds $v$. Sims, ${ }^{126}$ despite the embarrassing example of the constitutionally dictated basis for apportionment of the United States Senate, ${ }^{127}$ the Court held that both houses of the bicamerăl Alabama legislature were required under the equal protection clause to be apportioned on the basis of population, regardless of other legitimate interests that might be urged in favor of some deviation from population-based apportionment. Forgotten were the "well developed and familiar" equal protection standards, referred to in Baker, under which the Court determines whether state action satisfactorily responds to any legitimate policy. To this day, legislative apportionment remains one of the few contexts in which the courts, in the name of the equal protection clause, mandate the values that legislatures must pursue rather than placing limited restrictions on the field of values that can legitimately be pursued. ${ }^{128}$

The apportionment decisions did not represent a complete break with externally defined values. In fact, the Court could derive many of the underlying values of its apportionment decisions from the federal and state constitutions. ${ }^{128}$ Aside from the compromise originally necessary to deal with the problem of slavery, the United States Constitution employs proportion of population as the basis for apportioning representatives among the states. ${ }^{130}$ The Alabama Constitution required both houses of the legislature to be apportioned basically according to population, ${ }^{131}$ while the Tennessee Constitution dictated the number of qualified voters as the basis for apportionment of both houses. ${ }^{132}$ Thus, in each case the requirement of Reynolds was more faithful to the standard of the state constitution than the state legislature had been. Also, two years before Baker $v$. Carr, the Court, employing a wedge provided by gross racial discrimination, had concerned itself in Gomillion $v$. Lightfoot ${ }^{133}$ with the drawing of the boundaries of political units

${ }^{125} I d$. (emphasis in original).

126377 U.S. 533 (1964).

127 The United States Senate, of course, is apportioned to give each state an equal number of votes, rather than on the basis of population. Under the original provision of the Constitution senators were chosen by the legislature of each state. U.S. ConsT. art. I, \& 3, cl. 1. In 1913, the Constitution was amended to provide that senators be elected by the people of the state they represent. Id. amend. XVII.

${ }_{128}$ See Note, Legislative Purpose, Rationality, and Equal Protection, 82 Yale

L.J. 123, 152-54 (1972).

129 But see supra note 127 and accompanying text.

130 U.S. Const. art. I, § 2, cl. 3.

131 See Reynolds, 377 U.S. at 538-39.

132 See Baker, 369 U.S. at 188-89.

133364 U.S. 339 (1960). 
within a state. ${ }^{134}$ Thus, even Baker may be seen as an elaboration of existing, externally defined standards, rather than a break from them.

Even if we had a satisfactory notion of what a complete judicial break with externally defined values would be, the adjudicatory process would hardly be conducive to such discontinuity. The courts only decide cases that litigants bring to them, and litigants take clues about available claims from the justificatory sources judges employ. There is no doubt, however, that judicial decisions can be more or less organic outgrowths of judicial precedents, and that the apportionment cases owed relatively little to prior decisions. In a system that values continuity with the judicial past as one mechanism of objective constraint on judicial choice, such decisions at least require an added measure of persuasiveness on their substantive merits. Whether the substantive argument for the apportionment decisions ${ }^{\mathbf{1 3 5}}$ is persuasive in the face of the sparse support from judicial precedent (or original intentions) ${ }^{\mathbf{1 3 6}}$ is inevitably a matter of judgment about public values, including the value of judicial objectivity. And that judgment must be the Court's, for it has no one else's to give.

My concern here is with the way a court should approach these cases and with the way we should assess the courts' actions, not with the substantive decisions in the cases. I have suggested that, viewed from the perspective of institutional continuity, Roe $v$. Wade may be a more modest development than the legislative apportionment cases, a result contrary to the usual judgment. Nonetheless, judicial objectivity is not simply a matter of the judiciary looking to the past. If we think of judicial decisions in the organic way I have suggested, we must recognize that the judiciary is constrained not only by its institutional past, but by its present environment as well. The value judgments embodied in the decisions the courts are called upon to review are the major objective sources in the immediate environment that constrain judicial

184 The Court decided Gomillion under the fifteenth amendment, more clearly applicable by its language than the fourteenth. 364 U.S. at 346 . It should also be noted that between the time of Baker and Reynolds, the Court decided Wesberry v. Sanders, 376 U.S. 1 (1964), imposing a numerical apportionment requirement for federal congressional districts within a state.

135 Powerful arguments can be made in favor of the substance of the Court's approach in the apportionment cases. Although realization of political equality depends on a great deal besides legislative apportionment, see Buckley v. Valeo, 424 U.S. 1 (1976), a requirement of a strict numerical basis for apportionment provides at least symbolic affirmation of that ideal. On the independent importance of symbols in the political process, see Bennett, supra note 3, at 1088-1103. The problem of malapportionment, moreover, is one that legislatures themselves had an interest in ignoring. For these reasons, the Court could see its involvement as necessary to treat a serious public problem and as requiring less tolerant standards of review than in other contexts.

${ }^{138}$ See Brest, supra note 3, at 231. 
decisions.

\section{Judicial Treatment of Legislative Values}

The reapportionment cases, in their citation of the state constitutional provisions, illustrate that courts can rely upon objectively defined sources of value other than original intentions and judicial precedents. These sources are potentially unlimited, but it seems clear that the most important of them are the very governmental decisions under review. Policy judgments are affirmatively assigned in our society to legislatures and other political bodies. That fact defines an important part of the larger environment in which constitutional decisions are made; it inevitably directs the courts to decisions of those political bodies as external sources of values. ${ }^{137}$

The principal mechanism by which those decisions constrain judicial choice is through the presumption that they are constitutional. Judicial reliance upon legislative (or other political) determinations may, however, also enter the process of fourteenth amendment decisionmaking in more subtle ways. It may, for instance, provide some explanation for the contemporary attraction of the equal protection clause as a decisional vehicle.

The use of the equal protection clause is sometimes depicted as evidence that judges are pursuing personal policy preferences, in this case a preference for "equality."138 Much of this fire is directed at the legislative apportionment decisions, ${ }^{139}$ where the initial decisions represented a rather sharp break with prior decisions as well as a rejection of the legislative judgment that nonpopulation-based apportionment was permissible. In other contexts, however, framing the issue as one of equal protection allows the Court to make ready use of one legislative judgment in examining another.

The legislative contribution is perhaps most apparent when the equal protection claim is one of entitlement to a "benefit." 140 In theory, there is no obstacle to a claim of an absolute right to a benefit quite apart from whether the legislature had granted the benefit to others. There is support in the work of some moral philosophers for a "right"

137 See Greenawalt, Policy, Rights and Judicial Decision, 11 GA. L. REv. 991, 1044-47 (1977).

${ }^{183}$ See, e.g. Monaghan, supra note 4, at 354 n.6; see also Kurland, Ruminations on the Quality of Equality, 1979 B.Y.U. L. REv. 1, 18 (1979); Kurland, The Supreme Court, 1963 Term-Foreword: Equal in Origin and Equal in Title to the Legislative and Executive Branches of the Government, 78 HaRv. L. Rev. 143, 145-62 (1964). (1962).

139 E.g., Reynolds v. Sims, 377 U.S. 533 (1964); Baker v. Carr, 369 U.S. 186

140 See generally Bennett, supra note 48, at 1011-12. 
to some governmental actions traditionally viewed as granting "benefits." ${ }^{141}$ Moreover, a simple extension of the substantive due process notion to the benefits area could turn the failure to implement such a morally based right into the denial of a constitutional right. If judges viewed their task as the simple implementation of "personal" preferences on matters of public policy and held to such a view of moral entitlements, they might be expected to announce or act on the assumption of such a constitutional right.

A number of years ago, Frank Michelman seemed to advance just such a "welfare rights thesis."142 He inferred from the contrasting patterns of Supreme Court opinions dealing with subsistence welfare benefits on the one hand, and less basic forms of government largesse on the other, that the Supreme Court was motivated by the view that there was a constitutional right to the subsistence benefits. The Court did not acknowledge such a right to welfare; indeed it denied there was one. ${ }^{143}$ This Michelman attributed to prudential constraints that prevented the Court from fully implementing the right. ${ }^{144}$ Michelman seemed to suggest that the Court was using the equal protection clause as the handle for partial implementation of a right it fully believed in.

If Michelman meant that the Supreme Court consciously considered that there was a right to subsistence benefits, the thesis seems much too strong. ${ }^{145}$ The question of moral entitlement to subsistence benefits is deeply controversial among contemporary philosophers. ${ }^{\mathbf{1 4 6}}$ The pattern of cases on which Michelman relied seems more readily understandable if we assume that the Court was not setting off into uncertain philosophical waters but rather was strongly dependent on the guidance it received on questions of value from the very legislative actions under review.

When the legislature decides that a certain group is to receive welfare benefits, it is plausible for judges to view that legislative decision as grounded, at least in part, on a moral sense in favor of the right. The legislative value judgment does not, of course, satisfy the claim of the

141 See, e.g., A. Gewirth, Human Rights 41-66 (1982); $f f$. J. Rawls, A TheORY OF JUSTICE (1971).

142 See Michelman, supra note 12; Michelman, Protecting, supra note 25; Michelman, In Pursuit of Constitutional Welfare Rights: One View of Rawls' Theory of Justice, 121 U. PA. L. REv. 962 (1973); see also Grey, Procedural Fairmess and Substantive Rights, in Due Process (Nomos XVIII) 182 (J. Pennock ed. 1977); L. TRIBE, supra note $74, \S 11-4$, at 574 .

14s See Dandridge v. Williams, 397 U.S. 471, 487 (1970).

144 See Michelman, Protecting, supra note 25, at 17.

140 Michelman would apparently not now endorse such a strong statement of the welfare rights thesis. See Michelman, Constancy, supra note 25.

146 See Alexander, supra note 28, at 819-26. 
equal protection claimant; the equal protection claim usually arises only because the legislature has not provided the benefit to the individual or group before the Court. When the Court extends the benefit to a group not legislatively favored, it goes beyond the legislative judgment, but it can do so more readily and confidently because the legislature has itself taken a position on the controversial moral question that is central to the inquiry. If the Court's decisions upholding equal protection claims to welfare benefits are understood in this way the Court can be taken at its word that the plaintiffs' right to welfare is constitutionally dependent on the prior legislative decision.

\section{Objectivity and Authority Revisited: Dworkin's Thesis}

Obviously my account of judicial use of original intention, precedent, and political decisions in equal protection cases only roughly sketches how constitutional decisions are grounded in objective sources of value. I make no claim to having provided a full account of judicial objectivity. My aim has been more modest: to show that even controversial constitutional decisions can be understood as dependent on external sources; that three particularly important external sources are original intentions, judicial precedents, and the political decisions under review; and that, in general, courts operate in an environment in which they naturally seek out and apply external sources of values.

It might seem that the incompleteness of my account of judicial objectivity is all that separates objectivity in constitutional cases from constitutional authoritativeness. Ronald Dworkin attempts a fuller account and presents it as an appeal to the authority of moral philosophy. I want to suggest, therefore, how my position differs from Dworkin's.

Among contemporary commentators Dworkin has made the most ambitious attempt to understand judicial decisions in terms of externally defined values. As Dworkin conceives the process, judges should proceed in two steps. In the first step, judges identify the principles that provide the best possible justification of the institutional history they confront. In the second step, these principles are applied to solve the specific issues that arise in litigation.

Judicial precedents are an important part of the institutional history confronted by judges in the first step, but so are the "structures, conventions, and practices"147 the history reveals. The principles derived in this first step must cohere in some general theory of moral, political, and legal philosophy. According to Dworkin, the judge's duty 
of "political responsibility"148 demands such coherence insofar as the judge is capable of achieving it. Dworkin's call for the "fusion" of constitutional law and moral theory suggests that he views moral philosophy as playing a central role in the general theory that best justifies constitutional law. ${ }^{148}$

Dworkin recognizes that, at least in a mature adjudicatory system, it is unlikely that the entire institutional history can be accommodated within any single coherent philosophical scheme. Thus, judges will view part of the history they see as mistaken. They must "develop some theory of institutional mistakes."150 Dworkin is unclear about whether variations in the philosophical predispositions of individual judges can appropriately play any role in the first step when each judge formulates the theory that "best justifies" the institutional history; at times, however, he seems to see a legitimate role for values that may vary from judge to judge in the second step, the application of the theory to specific problems. ${ }^{151}$

This two-step model of judicial decisionmaking strikes a responsive chord, but not, I would suggest, because there is any reason to believe it is an accurate depiction of the way judges do operate, could be expected to operate, or for that matter should operate. Its appeal lies in the way it tracks a common model for describing the legal process more generally: law is first articulated, discovered, or made, and then applied. The relationship of judge and jury, legislature and court, legislature and administrative agency, and even appellate court and trial court can usefully be conceived in such terms. So can the now usually disdained vision of the common law as the judicial implementation of principles of natural law. In each of these contexts, however, an authority relationship-a basis for deriving contextually right answers or at least for weeding out wrong ones-is accepted. The trial court must follow the law as articulated by the higher court, the jury is obliged to follow the judge's instructions, a court is to implement the legislative command, and so is an administrative agency. Natural law, of course, is entitled to obedience in the nature of things. When a relationship of authority is settled, we are comfortable with the limited exercise of dis-

148 R. Dworkin, supra note 12 , at 87.

149 Dworkin believes constitutional enactments exemplify "a prior commitment to certain principles of political justice which, if we are to act responsibly, must . . . be reflected in the way the Constitution is read and enforced." Dworkin, supra note 4, at 472. It is presumably for this reason that Dworkin believes that the abstractly conceived intentions of the constitutional intenders can and should be treated as authoritative. See supra text accompanying notes 52-56.

${ }^{180} \mathrm{R}$. Dworkin, supra note 12 , at 121 .

151 Id. at 127. 
cretion by the subordinate body. ${ }^{152}$

The two stages in Dworkin's conceptualization of a single court's processes in constitutional law seem to be a function of the authoritative role he believes moral philosophy can assume in constitutional law. Without that assumption of authoritativeness, however, the reason for conceptualizing the process in two stages is unclear. Equally unclear is the reason for reaching out for a general theory to justify the entire corpus of institutional data and treating what cannot be justified within that theory as mistake. The pivotal point in Dworkin's explanation of the judicial task is his assumption of a duty of "political responsibility." This duty "condemns the practice of making decisions that seem right in isolation, but cannot be brought within some comprehensive theory of general principles and policies that is consistent with other decisions also thought right."163 It is not at all clear, however, that judges do or should conceive of themselves as having any such duty, at least in the extreme form that Dworkin endorses.

There are multiple strains in Western philosophical tradition, often counseling inconsistent resolutions of difficult problems of individual morality and political action. The attention of the courts, however, is directed by the adjudicatory process to the particular facts of a stream of "cases" and "controversies."154 To the extent that a judge formulates a coherent system of moral and political philosophy, that philosophy will surely be expressed in his resolution of cases. Judges are not, however, typically trained in moral philosophy; there is no reason to think that their personal views on questions of public policy will in the aggregate cohere in some general philosophical scheme of values; and there is no reason to think that all, or even one, will do a good or useful job of impressing a general theory on the large and unwieldy body of material that constitutes the institutional history judges confront. The various strains in western philosophy find their way into constitutional law, ${ }^{155}$ but that does not imply that it is the duty of one or of all judges to strive mightily to bring order to the whole.

The judge has a duty of consistency, to be sure, but that duty has traditionally been conceived in terms of a process focused on the facts of the case at hand and on rules of law that purport to order factual patterns at a much more particularistic level than general philosophical schemes. Cases are to be decided on the narrowest, not the most general ground; and where they are not, they can subsequently be read as if

162 See Sandalow, supra note 31, at 1038.

153 R. DwORKIN, supra note 12 , at 87.

164 U.S. CONST. art. III, $\S 2$.

156 See Bennett, supra note 48, at 1000-06. 
they had been. ${ }^{158}$ There may or may not, for instance, be some general philosophical theory that can accommodate both Brown v. Board of Education $^{\mathbf{1 5 7}}$ and Reynolds $v$. Sims. ${ }^{158}$ Any attempt at ultimate reconciliation must come to grips with the most difficult and basic issues of political philosophy. ${ }^{150}$ Nonetheless, each of these two cases has comfortably assumed a position in fourteenth amendment jurisprudence with no particular difficulty traceable to the uncertainty of their ultimate compatibility.

Moral philosophers recognize the responsibility of general theory to accommodate particular judgments. Frequently the most telling points that one school of philosophy makes against another are the counterintuitive results in particular cases suggested by the tenets of the school under attack. The monster who derives great utility from the suffering of others, for instance, is a perpetual source of embarrassment to utilitarianism and is just the most famous example. ${ }^{160}$ Moral philosophers do not even agree on the possibility of capturing our confident moral intuitions in a comprehensive moral theory, let alone on the content of such a theory. ${ }^{\mathbf{1 6 1}}$ The adjudicatory process, however, is directed to the particular in a way that moral philosophy is not. ${ }^{162}$ While moral philosophy can concentrate on the accommodation between general theory and particular intuitions, judges can concern themselves with such a reconciliation only by diverting energy from the more particularized focus that their assigned task of adjudication requires. ${ }^{163}$ For that rea-

156 See Cohens v. Virginia, 19 U.S. (6 Wheat.) 264, 399-400 (1821).

187347 U.S. 483 (1954).

158377 U.S. 533 (1964).

158 See Sager, Rights Skepticism and Process-Based Responses, 56 N.Y.U. L. REv. 417, 444-45 (1981).

${ }^{100}$ See Williams, A Critique of Utilitarianism, in J. SMart \& B. Williams, UTILITARIANISM, FOR AND AGAINST 105-06 (1973); see also Harsanyi, Can the Maximin Principle Serve as a Basis for Morality? A Critique of John Rawls' Theory, 69 AM. Pol. ScI. REv. 594, 595-96 (1975) (criticizing Rawls' maximin principle); Rae, $A$ Principle of Simple Justice, in Philosophy, Polrtics \& Society, 5th Series 135, 145-47, $151-53$ (P. Laslett \& J. Fishkin eds. 1979) (criticizing Rawls' maximin principle); $c f$. Sager, supra note 159, at 433-34 (raising a question about Dworkin's reliance on the distinction between personal and external preferences as limiting the appropriate reach of majoritarian decisions).

161 See, e.g., I. Berlin, Goncepts and Categories 1-11 (1978); T. Nagel, MoRTal Questions 128-41 (1979).

162 "The courts are concerned with the flesh and blood of an actual case. . . [This concern] . . . provides an extremely salutary proving ground for all abstractions; it is conducive, in a phrase of Holmes, to thinking things, not words . . . ." A. BICKEL, supra note 91 , at 26.

${ }^{163}$ See Deutsch, Neutrality, Legitimacy, and the Supreme Court: Some Intersections Between Law and Political Science, 20 Stan. L. REv. 169, 189-90 (1968). Kent Greenawalt suggests that, "If a judge tries self-consciously to emulate [Dworkin's superhuman judge] Hercules, he may be set adrift in abstractions he cannot really handle 
son alone, until the way to moral coherence is clearer, the law will inevitably treat coherence at the level of general theory as, at best, a secondary concern.

The difference between Dworkin's position and mine is one of degree and emphasis, but it is an important difference. Dworkin clearly understands that the task of reconciliation is a superhuman one, so that real judges can hope to succeed in it only to a degree, and I recognize that a judge has an important duty to make the law consistent. Nonetheless, the degree of abstraction at which judges concern themselves with consistency will strongly influence what they do in deciding cases. Given the present state of philosophical development, it seems to me that judges are more likely to achieve a real measure of consistency by concentrating on less abstract levels.

If Dworkin's aspirations for moral theory in constitutional law seem premature, however, that should not cause us to ignore the institutional role of the judge upon which he insists. ${ }^{164}$ It is in the understanding of the judge's institutional role-without Dworkin's assumptions about the power of moral philosophy to yield authoritative answers-that judicial objectivity in constitutional law can be found.

\section{Conclusion}

Virtually all contemporary students of constitutional jurisprudence recognize that judges' views on public values do and should play a role in their decisions. "Mechanical" jurisprudence has no visible contemporary adherents. One of the central concerns of constitutional scholarship has been to reconcile this recognition with the perceived need for judicial objectivity. The most common contemporary approach to resolving the dilemma has been a search for constitutional authoritativeness, that is, for a way to view judicial value choices as somehow subordinate to "higher level" choices authoritatively made.

So often the destructive part of constitutional scholarship is more persuasive than the constructive part. ${ }^{165}$ The reason, I think, is that the search for constitutional authoritativeness is misconceived, save perhaps as the text can now provide it, or moral and political philosophy some day may. In the case of the fourteenth amendment, the textual constraint is minimal, and that fact places in sharp relief the question whether judicial objectivity is possible without constitutional

and end up rationalizing his own preferences more than he would under some simpler process of decision." Greenawalt, supra note 137, at 1043 (footnote omitted).

104 See Greenawalt, supra note 137, at 1044.

165 See generally Brest, supra note 54. 
authoritativeness.

It is apparent why questions of judicial objectivity and constitutional authoritativeness resist separation. If judges' choices among public values are carried on within objectively defined constraints, it must be because judges respond to a sense of duty to draw from those external sources. Any such sense of duty will be difficult to distinguish from the duty felt to be owed to sources of authority.

It is, I believe, nonetheless useful to force the separation. The usually proffered sources of authority are radically different from one another. Originalists appeal to the authority of those who enacted the Constitution, non-originalists to some moral or political ideal. What they have in common is an appeal to constraint on judicial choice that can be abstracted from the judicial process of decision by adjudication and then reimposed to govern particular decisions. The real constraint on judicial choice, however, is produced by engaging in the process of decision, rather than by governance from outside. It is an appreciation of the role of this process and of the environment in which it takes place in producing both judicial restraint and the ever developing substance of constitutional law that justifies distinguishing judicial objectivity in constitutional law from obedience to authority. 